\title{
What can management option uptake tell us about ecosystem services delivery through agri-environment schemes?
}

Arnott, David; Chadwick, David; Harris, Ian; Koj, Aleksandra; Jones, David L.

\section{Land Use Policy}

DOI:

10.1016/j.landusepol.2018.10.039

Published: 01/02/2019

Peer reviewed version

Cyswllt i'r cyhoeddiad / Link to publication

Dyfyniad o'r fersiwn a gyhoeddwyd / Citation for published version (APA):

Arnott, D., Chadwick, D., Harris, I., Koj, A., \& Jones, D. L. (2019). What can management option uptake tell us about ecosystem services delivery through agri-environment schemes? Land Use Policy, 81, 194-208. https://doi.org/10.1016/j.landusepol.2018.10.039

\section{Hawliau Cyffredinol / General rights}

Copyright and moral rights for the publications made accessible in the public portal are retained by the authors and/or other copyright owners and it is a condition of accessing publications that users recognise and abide by the legal requirements associated with these rights. study or research.

- Users may download and print one copy of any publication from the public portal for the purpose of private

- You may not further distribute the material or use it for any profit-making activity or commercial gain

- You may freely distribute the URL identifying the publication in the public portal ?

Take down policy

If you believe that this document breaches copyright please contact us providing details, and we will remove access to the work immediately and investigate your claim. 
1 What can management option uptake tell us about ecosystem services delivery through

2 agri-environment schemes?

3 David Arnott $^{\mathrm{a},{ }^{*}, \text { David Chadwick }}{ }^{\mathrm{a}}$, Ian Harris ${ }^{\mathrm{a}}$, Aleksandra Koj ${ }^{\mathrm{b}}$, David L. Jones ${ }^{\mathrm{a}, \mathrm{c}}$,

$4 \quad$ a School of Natural Science, Environment Centre Wales, Bangor University, Bangor, Gwynedd, $5 \quad$ LL57 2UW, UK.

$6{ }^{\mathrm{b}}$ Geoenvironmental Research Centre, Cardiff University, Queen`s Building, Newport Road, $7 \quad$ Cardiff, CF24 3AA, UK.

$8{ }^{c} U W A$ School of Agriculture and Environment, University of Western Australia, Crawley, WA 9 6009, Australia. 
ABSTRACT

Agri-environment schemes (AES), currently embedded in EU and UK policies, actively promote 'greening', 'sustainability' and 'ecosystem services' approaches to land management. The funding structures of these policies, however, run counter to this sustainable approach, and create barriers to AES success, primarily through a continued focus on productivity support. In this study, we aim to determine the effectiveness of action-based AES, as a delivery mechanism for ecosystem services, using secondary data analysis techniques to unravel the complexities of AES funding distribution and scheme structure and geographic information systems (GIS) to explore the spatial extent and uptake of AES management options, using Wales, UK as a study area. Our results show $84 \%$ of recipients of AES payments receiving < $£ 10 \mathrm{k}$ annually, comprising only $35 \%$ of the total available funding. 15 , out of a total of $\sim 165$, management options, accounted for $>75 \%$ of all advanced level management contracts awarded in both 2015 and 2017. This bias in option uptake, in many cases, positively prevents further deterioration of existing habitat condition through a 'business as usual' approach. However, we argue that the voluntary, over prescriptive nature of the schemes limits management option uptake, negatively impacts on the schemes ability to deliver ecosystem services, and lessens the government's ability to promote long-term behavioural change. If AES are to deliver the "'Public Goods" that future policy demands, then targeted and adequate levels of funding and a willingness to participate must be combined with greater farmer autonomy and clear outcomes to deliver management options at a landscape scale.

Keywords: Conservation; Ecosystem services; Glastir; Habitat management. Land use policy.

\section{Introduction}

The 'Sustainable growth: natural resources' category funds the Common Agricultural 
Guarantee Fund (EAGF) (Pillar 1) which makes payments directly to farmers, and funds measures to regulate agricultural markets, and second, is the European Agricultural Fund for Rural Development (EAFRD) (Pillar 2) which aims to develop rural economies and increase the productivity of farming and forestry. As a direct result of the 23rd June 2016, UK referendum on EU membership, the UK payment structure is facing reform and is likely to move away from this two Pillar structure (Helm, 2017; Dwyer, 2018; Gove, 2018). Future financial support is expected to pay farmers to deliver clear environmental or 'public good' benefits rather than through direct payments (Gove, 2018; WG, 2018). In the EU, an average of $16.8 \%$ of the EAFRD is spend on Agri-Environment-Climate contracts but in the UK, this currently varies between the devolved nations (Gravey, et al., 2017). The Welsh Government (WG) views agri-environment schemes (AES) as, "the state ... buying environmental goods and services ("Public Goods") from farmers who would otherwise not supply them" (Rose, 2011). This would suggest, that in Wales, structures are in place to meet the UK government's challenge (Gove, 2018) to enhance our natural environment and hand on a country, and a planet, in a better state than we found it. The current 'action-based' AES schemes, employed across the UK to deliver environmental outcomes, include a suite of land management 'options', designed to ensure the availability of suitable options, across all land types, within the remit of the particular scheme (Rose, 2011; Munday, 2018). However, the prescriptive nature of this type of scheme is often seen as a barrier to scheme uptake (Wilson and Hart, 2000) and long-term behaviour change (de Snoo et al., 2013). The cost-effectiveness (Ansell et al., 2016), and ecological impact of this type of 'action based' AES, on birds (McHugh et al., 2016; Princé et al., 2012; Sabatier et al., 2012: McHugh et al., 2016), insects (Wood et al., 2015; Caro et al., 2016) and biodiversity (Kleijn and Sutherland, 2003; Kleijn et al., 2006; Fuentes-Montemayor et al., 2011; Wilkinson et al., 2012; Ekroos et al., 2014) is also widely debated in the literature. Many suggest schemes which link payments to the provision of 
61 desired environmental outcomes, rather than to prescribed management activities, could

62

63

64 represent a more effective way of rewarding farmers for the delivery of "Public Goods" (Matzdorf and Lorenz, 2010; Sabatier et al., 2012; Moxey and White, 2014; Russi et al., 2016). It is also argued that 'results-based' schemes are more effective at enhancing social capital (Burton and Schwarz, 2013) and redirecting much needed funding to marginal upland, and some lowland areas, where income streams are low (Helm, 2017). Current studies consider the advantages, and disadvantages of both action, and results-based AES, in determining effectiveness but we found none that focus on the impact that option uptake and payment distribution may have on effectiveness.

In the present study, we aim to determine if current action-based AES are an effective means of delivering ecosystem services, using Wales as a study area. We achieve this by using secondary data analysis techniques to unravel the complexities of AES funding distribution and scheme structure, and GIS to explore the spatial scale and uptake of AES management options. We discuss the findings to establish if the payment distribution and option management structures of AES, currently funded through the CAP, provide effective ecosystem services delivery, or additional income support streams for farmers in low production areas. In conclusion, we suggest how a UK exit from the EU can provide policymakers with the opportunity to design AES which can effectively deliver "Public Goods", whilst subsequently providing farmers with the additional human and social capital needed to fully support social, economic and cultural objectives in Wales. 
Methodology

\subsection{Study area}

Wales was selected as the case study area for its focus on sustainability (WG, 2015a; WG, 2016a; WG, 2017a), and for the following reasons: (i) agriculture being the dominant land use ( $84 \%$ of the total land area of 2.1 million ha; WG, 2017b), (ii) the proportion of famers who participate in AES (in 2017, 4781 farmers received AES payments, representing 13\% of the total number of holdings in Wales; Defra, 2017b), (iii) the low average income of most farmers and their reliance on Direct and AES payments (62\% of cattle and sheep farms (less favoured area, LFA) either made a loss or would have done so without subsidy, compared with $41 \%$ of cattle and sheep (lowland) farms and 44\% of dairy farms; WG, 2017c), (iv) amount of land (0.8 million ha) being in higher or entry level AES (JNCC, 2017a), and (v) the availability of reliable AES data.

\subsection{CAP payments data}

Secondary data analysis techniques were used to identify the extent, and distribution, of current spending on agri-environment schemes (Johnston, 2014). The 2015/2016 CAP payments datasets, published for transparency by Defra (2017b) in compliance with Regulation (EU) No 1306 (EC, 2013) and Commission Implementing Regulation (EU) No 908 (EC, 2014), were used as the primary data source. Produced for accountability at both UK and EU governmental levels, these datasets are an accurate reflection of spending on rural development (Pillar 2) in the UK.

The dataset variables include funding categories, payment beneficiaries and total farm payment received. We created agricultural production, social, agri-environment and support and forestry, target area variables and assigned funding categories to the relevant target area based on descriptions found in Wales' 2014-2020 Rural Development Programme (WG, 2017d). We summed funding category payments in each focus area giving total expenditure 
per target area category and expressed these as a percentage of total Pillar 2 expenditure. We expressed total AES expenditure as a percentage of total Pillar 2 and of total CAP expenditure. The total number of recipients receiving financial support through both Pillar 1 and Pillar 2 payments and those receiving payments for agri-environment were collated to quantify the percentage of 'active farmers' enrolled in AES.

Payments were collated by postcode prefix (first two letters (postcode area) = postal town/ postcode district; number following postcode area = location within the postal town boundary) and a detailed analysis was conducted to identify the total number of recipients, the total payment per district and the mean farm-level payment. The total number of payment recipients and the total payments expenditure within the postcode district was expressed as a percentage of the total recipients and expenditure across Wales. Sixteen payments categories in the range $£ 0-400 \mathrm{k}$ recipient ${ }^{-1}$ were generated and the total number of recipients and total payments made identified in each of the payment ranges.

\subsection{Glastir AES data} sustainable land management (Rose, 2011). Rural Payments Wales (2017) provided anonymised ESRI ArcInfo polygon shapefiles, mapped to OS Mastermap features at a 1:10000 scale, for the Glastir Entry (GE), Glastir Advanced (GA), Glastir Commons (GC), Glastir

Woodland Creation (GWC) and Glastir Woodland Restoration (GWR) elements for the years 2015 and 2017. The first 5 year Glastir contracts started on $01^{\text {st }}$ January 2012 and ended on $31^{\text {st }}$ December 2016 (WG, 2012). Access to both the 2015 and 2017 datasets allowed for comparisons between option uptake pre and post the end of the first 5-year contractual period. Appendix A. 

categories (Habitat, Tree, Infrastructure and access, Water and drainage, Stock, Wildlife, Agrimanagement, Vegetation and birds). In this study, we extracted management option descriptions from the RPW attributes data (RPW, 2017) and grouped them by Natura 2000 management categories. We used the total number of management contracts awarded to identify the most popular 15 options, and the most prominent management categories, for GA and GE. Appendix B contains further details on the breakdown of each of the management categories. ArcGIS-ArcMap 10.4.1 (ESRI, 2017) was employed to conduct a spatial analysis of the options data using overlay and geoprocessing techniques. Comparisons were made with the Predictive Agricultural Land Classification (ALC) Map 2017, designed on a $50 \mathrm{~m}$ raster (1:50,000) (WG, 2017e) and the Habitat Land Cover Map 2015 (LCM2015; CEH, 2017) supplied as a vector product with a minimum mappable unit of 0.5 ha and a minimum feature width of $20 \mathrm{~m}$.

\section{Results}

\subsection{CAP and AES payments to farmers in Wales}

151 The UK receives a total of $£ 2.8$ billion per year from the EU to cover payments made under 152 CAP. Pillar 1 gives around $£ 2.3$ billion per year to UK farmers mainly under the Basic Payments Scheme (BPS), provided they carry out certain agricultural activities and comply with standards in areas such as food safety, animal welfare, environmental protection and land maintenance. Pillar 2 gives $£ 0.6$ billion of EU funding per year to fund rural development programmes in the UK (NAO, 2017). In 2016, total spending in Wales was £248 million with $£ 190$ million allocated to Pillar 1 and $£ 58$ million to Pillar 2 (Fig. 1). 


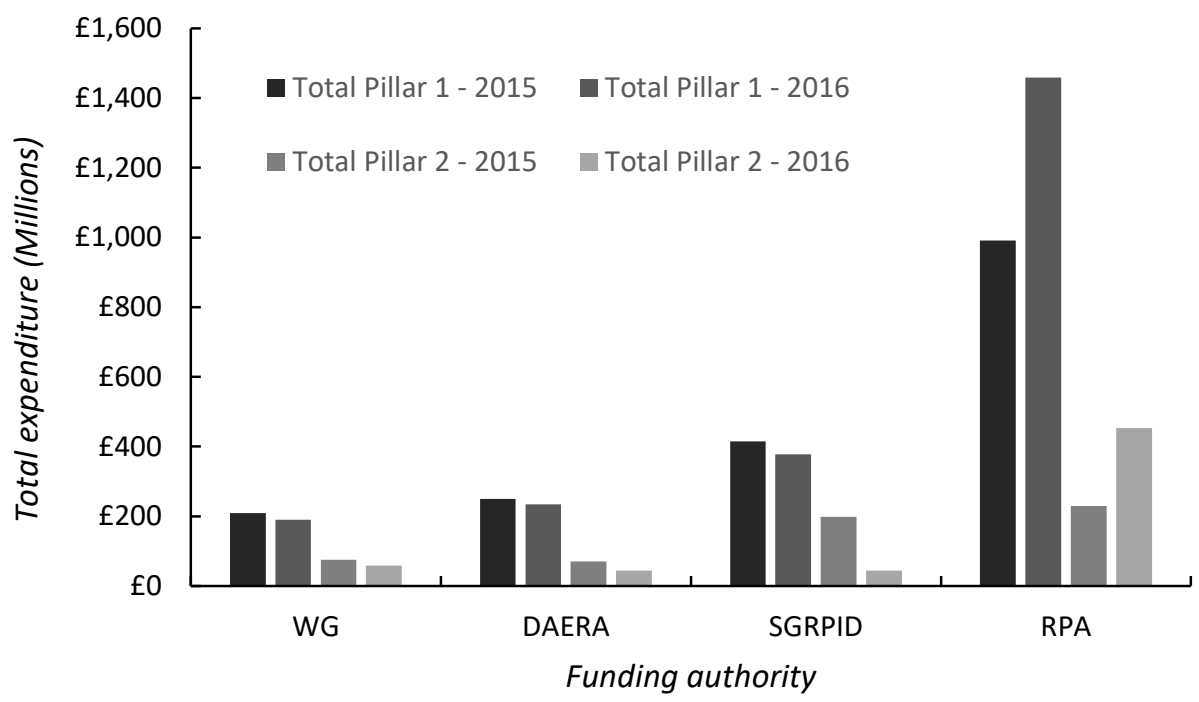

158

Figure 1. Total UK spending on Pillar 1 and Pillar 2 subsidies for the 2015/16 period divided by individual country. WG (Welsh Government), DAERA (Department of Agriculture, Environment and Rural Affairs, Northern Ireland), SGRPID (Scottish Government Rural Payments and Inspections Directorate) and RPA (Rural Payments Agency, England). (DEFRA, 2017).

Table 1 shows the distribution of Pillar payments by funding category and focus area.

Overall, $63 \%$ of Pillar 2 funding was spent on AES (2.2\% in admin support) and 23\% in support

of production with the remainder split on administration (3.2\%), forestry creation and

restoration $(8.4 \%)$ and support for social enterprises $(2.4 \%)$.

Table 1. Distribution of Pillar 2 subsidies in Wales by funding categories and focus area (DEFRA, 2017).

\begin{tabular}{|c|c|c|c|}
\hline Funding category & $\begin{array}{l}\text { Payment } \\
(\mathfrak{( f )}\end{array}$ & $\begin{array}{l}\text { Payments } \\
(\% \text { of total })\end{array}$ & Focus area \\
\hline Technical assistance & $1,849,989$ & 3.2 & Administration \\
\hline Non-productive investments & $1,288,860$ & 2.2 & Agri-environment (Support) \\
\hline Agri-environment-climate & $27,834,285$ & 47.8 & Agri-environment \\
\hline Agri-environment payments & $7,573,423$ & 13.0 & Agri-environment \\
\hline $\begin{array}{l}\text { Investments in physical } \\
\text { assets }\end{array}$ & $7,657,814$ & 13.0 & Production \\
\hline Organic farming & $3,957,679$ & 6.8 & Production \\
\hline $\begin{array}{l}\text { Development of new } \\
\text { products, processes and } \\
\text { technologies }\end{array}$ & 942,128 & 1.6 & Production \\
\hline $\begin{array}{l}\text { Modernisation of } \\
\text { agricultural holdings }\end{array}$ & 883,297 & 1.5 & Production \\
\hline $\begin{array}{l}\text { Implementing local } \\
\text { development strategies } \\
\text { Implementing cooperation } \\
\text { projects }\end{array}$ & 33,810 & 0.1 & Production \\
\hline
\end{tabular}


Investment in forest area

development and

improvement of forest

viability

$\begin{array}{lll}3,222,356 & 5.5 & \text { Forestry }\end{array}$

Adding value to agricultural

and forestry products

First afforestation of

agricultural land

First afforestation of non-

agricultural land

Implementing local

$\begin{array}{lll}1,532,227 & 2.6 & \text { Forestry }\end{array}$

$\begin{array}{lll}106,051 & 0.2 & \text { Forestry }\end{array}$

$\begin{array}{lll}17,132 & 0.1 & \text { Forestry }\end{array}$

development strategies.

Quality of

life/diversification

Basic services for the

economy and rural

population

Skills acquisition, animation

366,332

$0.6 \quad$ Social

and implementation of local

244,731

$0.4 \quad$ Social

development strategies

Vocational training and

information actions

Running the local action group, acquiring skills and

animating the territory

456,453

$0.8 \quad$ Social

Payments to farmers in areas

with handicaps, other than

mountain areas

168

\begin{tabular}{lrrr} 
& 48.87 & 0.1 & Social \\
\hline Total & $58,289,654$ & 100.0 & \\
\hline
\end{tabular}

Analysis of AES payments and recipient numbers by postcode areas showed the North-

West region (LL postcode) received the largest proportion of AES funding and has the highest

levels of participation. The South-West region (SA postcode) had slightly lower levels of participation but funding does not match that of the North-West suggesting participation occurring on a smaller scale (Fig. C1). We observed uneven distribution patterns between payment ranges (Fig. 2). Analysis of farm payment data revealed that $84 \%$ of recipients of AES payments were in the $£ 0-10 \mathrm{k}$ category, comprising only $35 \%$ of the total available funding. Of these, $54 \%$ of the recipients received $<£ 4 \mathrm{k} \mathrm{year}^{-1}$ (Fig. C2). In contrast, $<1 \%$ of the total number

177 of recipients received payments exceeding $£ 100 \mathrm{k}$, accounting for $14 \%$ of the total available funding. 


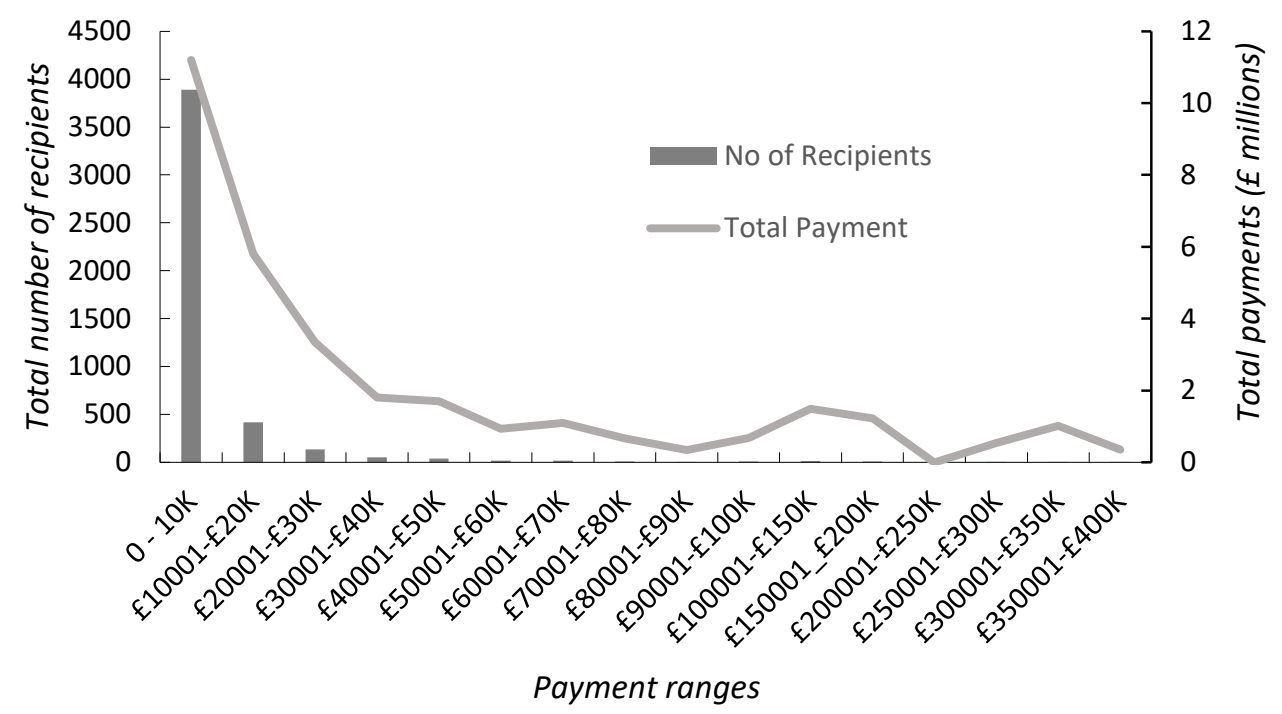

Figure 2. Distribution of 2016 agri-environment payments in Wales/UK showing the total number of recipients and the total payments received by payment range (DEFRA, 2017).

\subsection{Distribution of options within the Glastir entry $(G E)$ and Glastir advanced (GA) AES}

Glastir is the latest in a line of AES which has seen land involved in Welsh AES rise from 0.01 million ha in 1992 to 0.25 million ha in 2016 (Banks and Marsden, 2000; JNCC, 2017).

Glastir contracts consist of a Whole Farm Code (WFC), which contains general rules affecting all land on the farm, and various management options (Table C1; Table C2). In GE level schemes, farmers select options that meet or exceed a point's threshold related to the area of eligible land on the farm entered into the scheme (WG, 2015b). In GA level schemes, applying farms are assessed for their ability to deliver against objectives (WG, 2015c). The maps in Figure 3 show the uptake and distribution of management options within land parcels entered into agreements under the Land Parcel Identification System (LPIS; see Appendix A for further details of the LPIS). This enabled us to highlight the levels of spatial overlap between schemes, especially at GA and GE levels where, prior to 2015, participation in the lower level scheme was a prerequisite for entry into the higher. Our study shows the greatest concentration of AES management options occurring in upland unimproved agricultural areas (Agricultural land classes 4 and 5; Fig. 4a) predominantly comprising of acid and calcareous grasslands and heather moorland habitats (Fig. 4b). 
(a) Agri-Environment Mangement Options

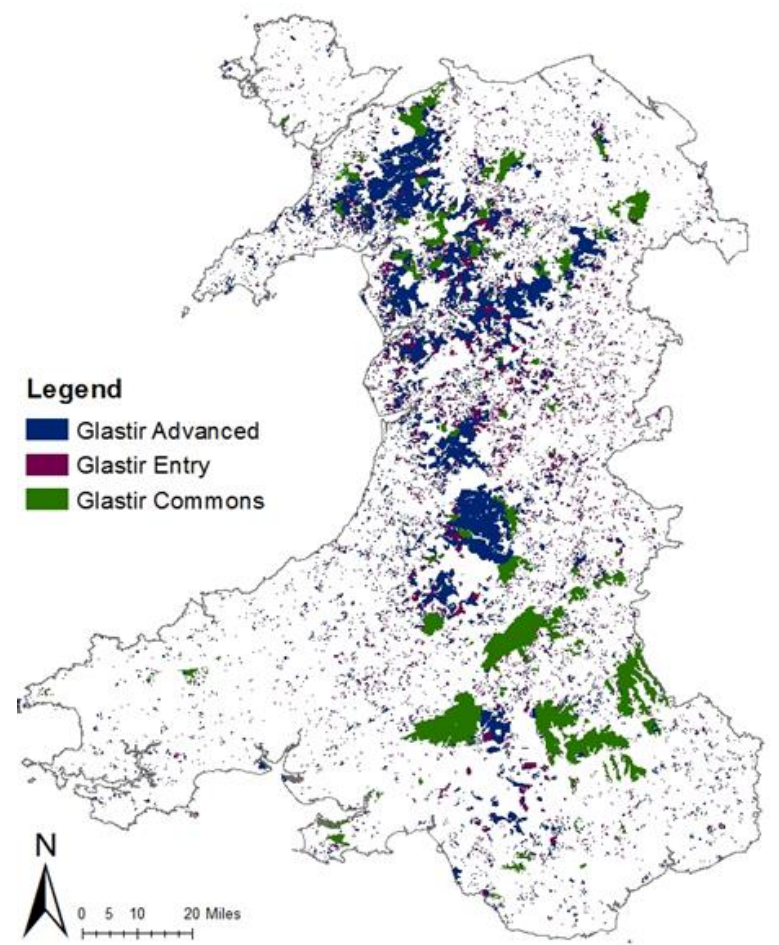

(c) Glastir Entry (GE) Options

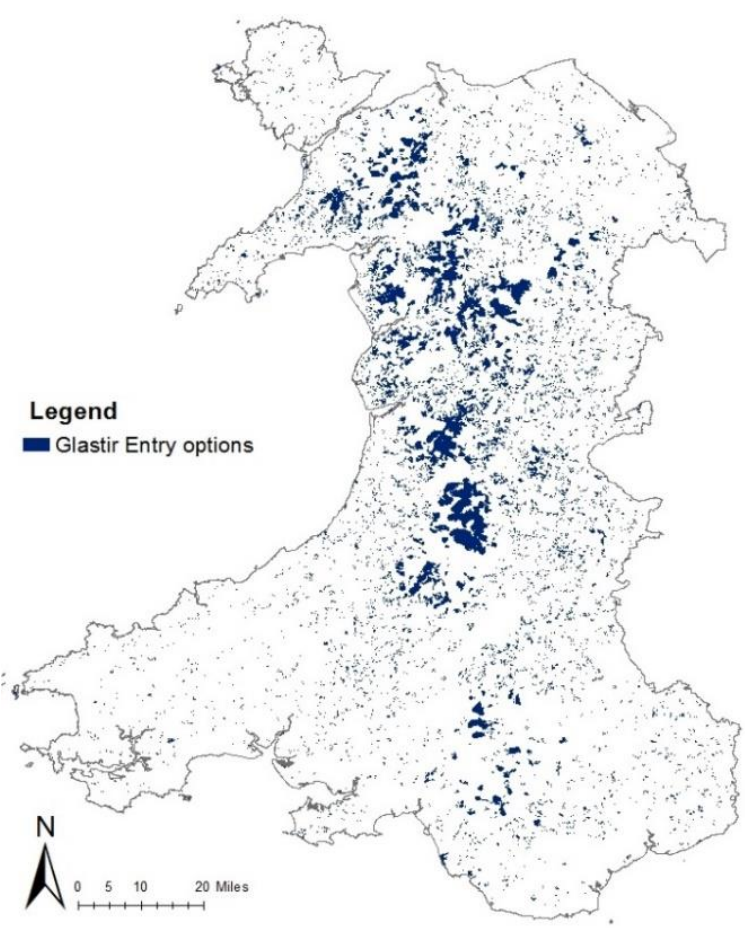

(b) Glastir Commons (GC)

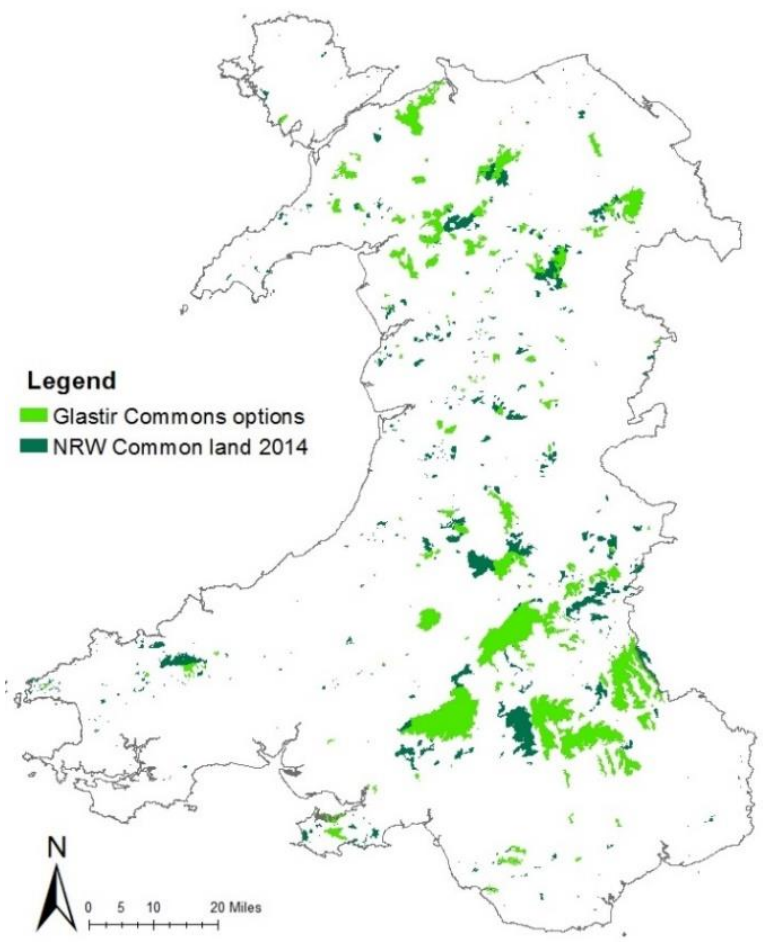

(d) Glastir Advanced (GA) Options

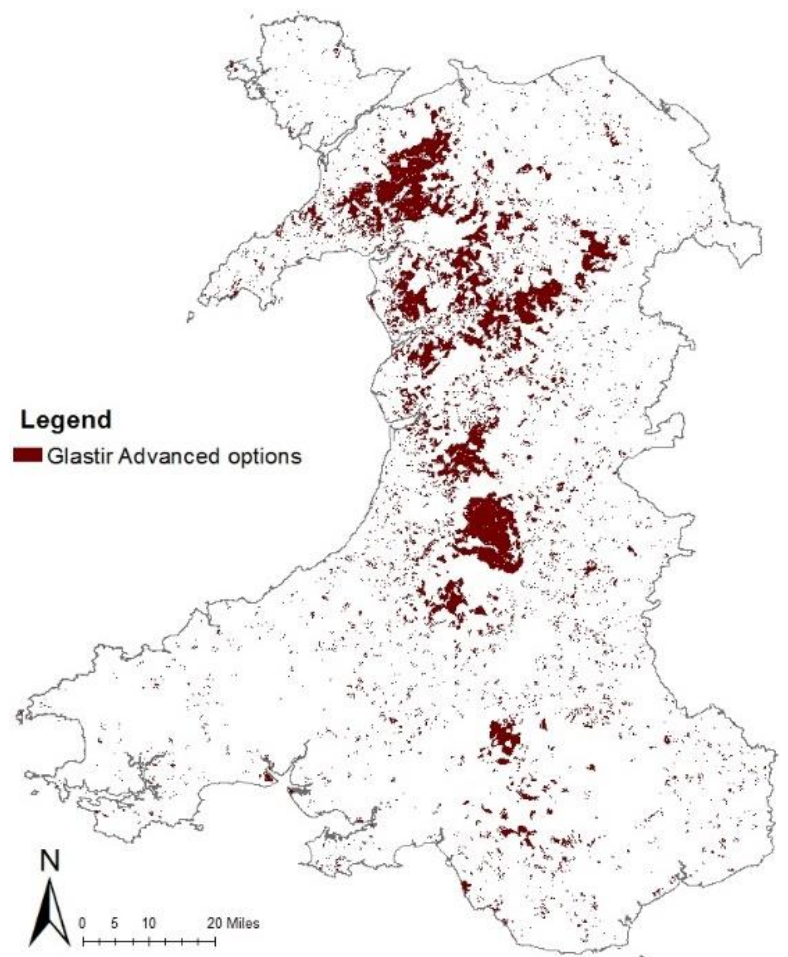

Figure 3. Scale and concentration of targeted management options within land parcels entered into the agreement under the land-parcel identification system (LPIS) in Wales. (a) Combined agri-environment schemes, (b) Glastir Commons superimposed onto the NRW (2014) Registered Common Land map (RPA, 2017), (c) Glastir Entry, and (d) Glastir Advanced. () RPA /NRW/WG. (c) Crown copyright / database right 2017. An Ordnance Survey / EDINA supplied service. 

woodland regeneration $(G W R)$

In 2016, GC covered 118,000 ha of common land (JNCC, 2017). This was significantly higher that under the predecessor to Glastir (Tir Gofal, 1999-2011), where agreements covered only $2 \%$ of the common land in Wales (WG, 2015d). By superimposing the 2017 GC dataset onto the NRW (2014) Registered Common Land Map we were able to create a GC distribution map (Fig. 3b) showing GC management options covered $65 \%$ of common land, principally upland habitats.

"Woodlands for Wales", the Welsh Government's fifty-year strategy for promoting woodland planting and management in Wales, was published in 2001 and revised in 2009 (WG, 2015e). It contained an aspiration to create 100,000 ha of new woodland between 2010 and 2030 as a means to help Wales meet its carbon emission reduction targets (WG, 2010; WG, 2016b). The latest indicators of its success (WG, 2015e), however, showed a slight decrease in the estimated area of woodland cover in Wales from 2001-2010. With a requirement to deliver woodland planting at a rate of 5,000 ha annum ${ }^{-1}$ this target was subsequently assessed to be unachievable and a government-commissioned review in 2014 amended the aspiration to 50,000 ha by 2040 (WG, 2016b). We show the uptake of GWC options across the country to be very limited, occurring on a small scale and often located on existing acid grasslands (Fig. 4b; Fig. 4d). GWR options aim to replant areas of larch Larix decidua felled to help prevent the spread of Phytophthora ramorum disease (WG, 2017c). Fig. 4d shows a greater uptake of GWR options than GWC, restoring woodland in areas currently devoid of trees, (Fig. 4c). Uptake of GA and GE level woodland options is low and sporadically distributed throughout the country (e.g. GA woodland options made up only $9 \%$ of the total option uptake in 2015 , dropping to $3 \%$ in 2017 ; Fig. $4 d$ ). 
a) PALC map - Wales (2017)

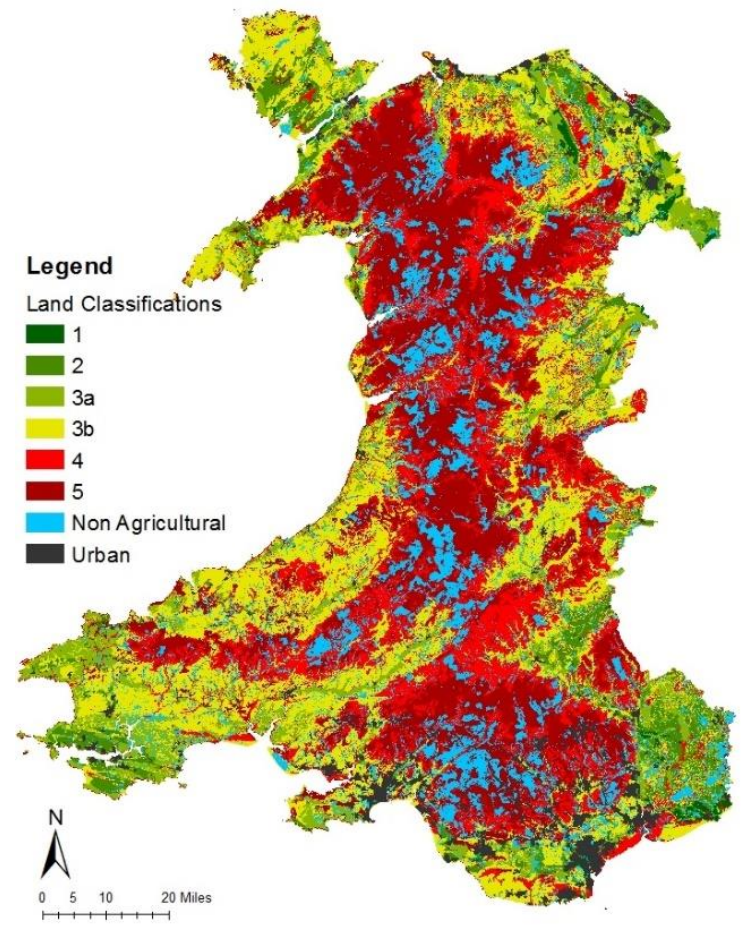

(c) Woodland Cover - CEH LCM (2015)

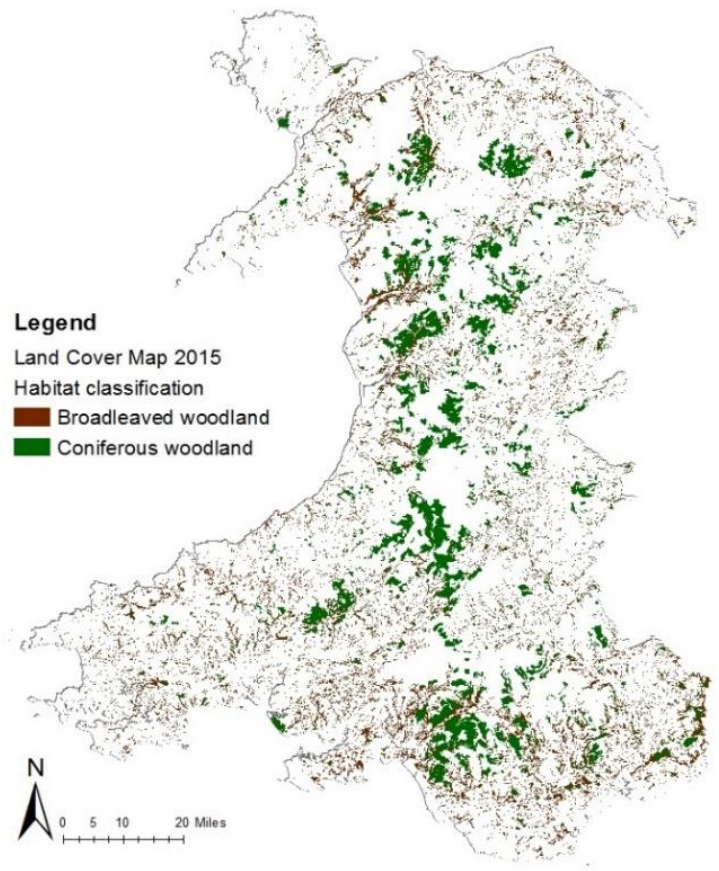

(b) CEH Land Cover Map - Wales (2015)

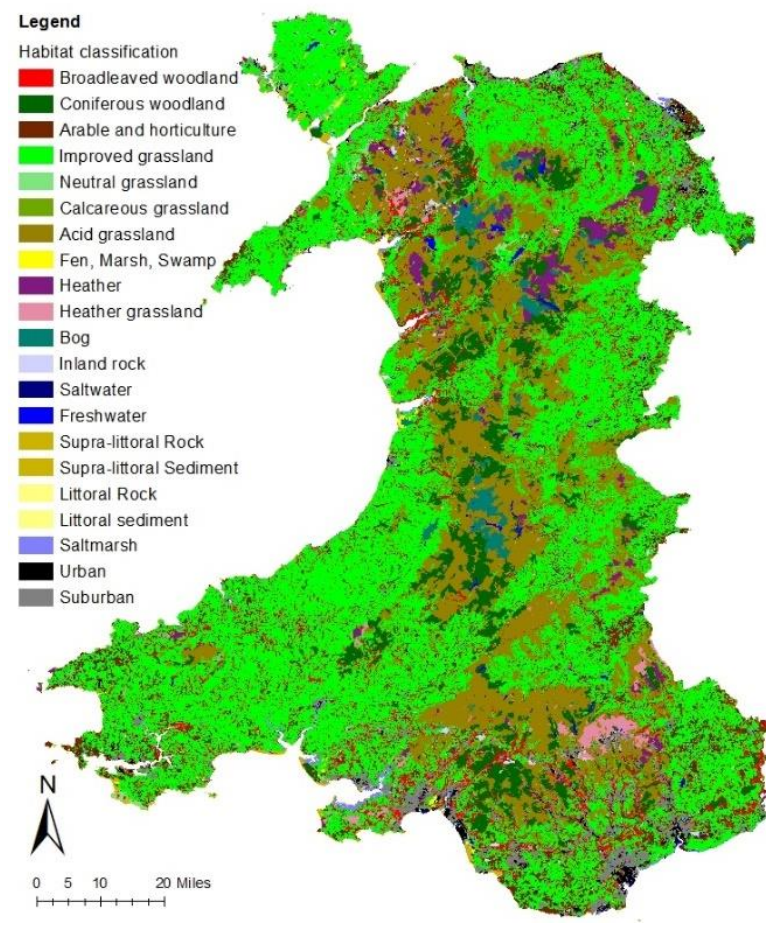

(d) Glastir - Tree Management

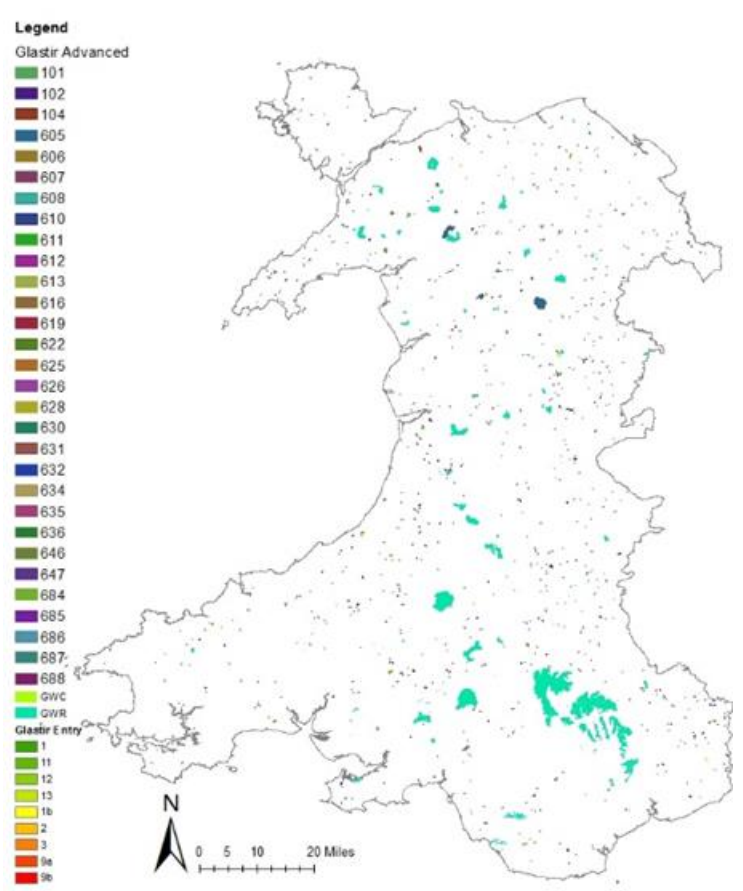

Figure 4. (a) Predictive Agriculture Land Classification (PALC) (See Appendix A for land classification descriptions). (b) Land Cover map for Wales. (c) The distribution of woodland habitats in Wales and (e) The woodland management options delivered through Glastir Advanced, Entry, Woodlands Creation and Woodlands Restoration. (RPA, 2017; CEH, 2017; WG, 2017e). (C) Welsh Government (C) Crown copyright / database right 2017. An Ordnance Survey / EDINA supplied service. 


\subsection{Glastir management options and land management categories}

Glastir AES contracts are issued for a five-year period. In 2015, there were 168 targeted GA and 57 GE management options available to farmers. In 2017, the number of managed options had changed, 166 for GA (Table B1) and 61 for GE (Table B2). Of those, 15 management options accounted for $>75 \%$ of all management contracts awarded in both 2015 and 2017. Further, ca. $40 \%$ of all GA and GE management options were targeted towards low or no input grazed pasture or woodland stock exclusion (Table 2). In 2017, 78 of the 166 GA options, individually, comprised $\leq 0.1 \%$ of the total option uptake. Of these 35 options had $<10$ contracts awarded per option.

Table 2. Top 15 management agri-environment scheme options adopted by farmers in the Glastir Entry (GE) and Glastir Advanced (GA) schemes in 2017 (RPA, 2017).

\begin{tabular}{|c|c|c|}
\hline Option description & $\begin{array}{l}\text { No. of contracts } \\
\text { awarded }\end{array}$ & $\begin{array}{l}\text { Options } \\
\text { (\% of total) }\end{array}$ \\
\hline \multicolumn{3}{|l|}{ Glastir Entry $(G E)$} \\
\hline 1. Grazed pasture - no inputs & 10759 & 18.2 \\
\hline 2. Grazed pasture - low inputs & 10547 & 17.9 \\
\hline 3. Management lowland marshy grassland & 5306 & 9.0 \\
\hline 4. Hedgerow management - both sides & 3253 & 5.5 \\
\hline 5. Hedgerow management external boundary ( 1 side only) & 3128 & 5.3 \\
\hline 6. Continued management of existing streamside corridor & 2886 & 4.9 \\
\hline 7. Enhanced hedgerow management - both sides & 2180 & 3.7 \\
\hline 8. Grazed pasture - low inputs and mixed grazing & 2105 & 3.6 \\
\hline 9. Hedgerow restoration without fencing & 1931 & 3.3 \\
\hline 10. Hedgerow restoration with fencing & 1681 & 2.8 \\
\hline 11. Maintenance existing hay-meadow & 1634 & 2.8 \\
\hline 12. Grazing management of open country & 1345 & 2.3 \\
\hline 13. Grazed pasture - no inputs and mixed grazing & 1201 & 2.0 \\
\hline $\begin{array}{l}\text { 14. Create streamside corridor on improved land on both } \\
\text { sides of a watercourse }\end{array}$ & 1170 & 2.0 \\
\hline $\begin{array}{l}\text { 15. Create streamside corridor on improved land on one } \\
\text { side of a watercourse }\end{array}$ & 955 & 1.6 \\
\hline Total & 50081 & 84.9 \\
\hline \multicolumn{3}{|l|}{ Glastir Advanced (GA) } \\
\hline 1. Grazed pasture - no inputs & 11391 & 20.6 \\
\hline 2. Woodland - stock exclusion & 10438 & 18.9 \\
\hline 3. Lowland marshy grassland & 2758 & 5.0 \\
\hline 4. Management lowland marshy grassland & 2657 & 4.8 \\
\hline 5. Grazed pasture - low inputs & 2531 & 4.6 \\
\hline 6. Additional management payment - reduce stocking & 2246 & 4.1 \\
\hline
\end{tabular}


7. Grazing management of open country

8. Streamside corridor management

9. Hard surfacing

10. Maintenance existing hay-meadow

11. Enhanced hedgerow management - both sides

12. Scrub clearance - hand

13. Bracken control - mechanical two cuts/year

824

14. Lowland unimproved acid grassland

636

15. Grassland managed with no inputs between Oct. and Jan

Total

631

42084

1.5

\subsection{Habitat management}

The uptake of habitat management options exceeded all other management categories in both GA and GE across both years (Fig. B1). Overall, 58\% of GA options were targeted at habitat management and $19 \%$ to stock management while for GE, $44 \%$ of the options delivered habitat management in the form of grazed pastures and stock reduction/exclusion (Fig. 5). Comparison between the distribution of zero, (Fig. 5cd) or low-input (Fig. 5e), grazing options and management of open countryside (Fig. 5f) with land cover (Fig. 4b) found the greatest concentration of these options occur on acid or calcareous grasslands (ALC class 4 and 5) where there is little history of land improvement or nutrient input (i.e. business as usual) regardless of entry in AES. These options will help ensure the maintenance of low or no input situations, preventing increases in nutrient burdens over the 5-year contractual period.

\subsection{Livestock exclusion/reduction and vegetation management}

Comparison between vegetation management options to promote biodiversity (Fig. 6b) and stock exclusion (Fig. 5a) and stock reduction (Fig. 5b) options shows significant overlap (i.e. conflict) within the same land parcels. Analysis of the extent of upland and lowland bracken cover (Fig. 6a) was shown to far exceed the levels of bracken control (Fig. 6b) provided through GA and GE management options. 
a) Glastir - stock exclusion options

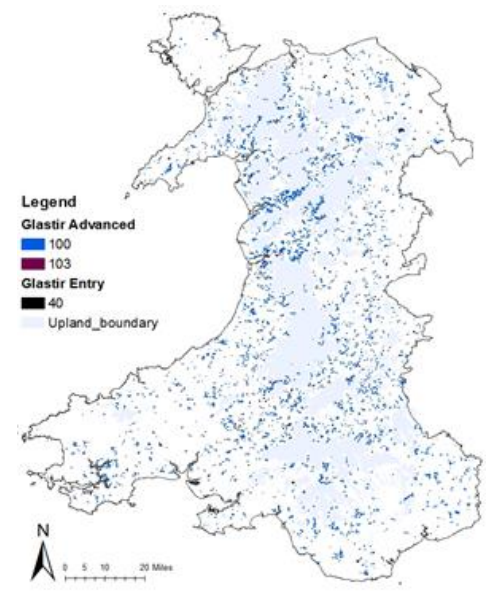

(c) Glastir - grazed pasture no inputs

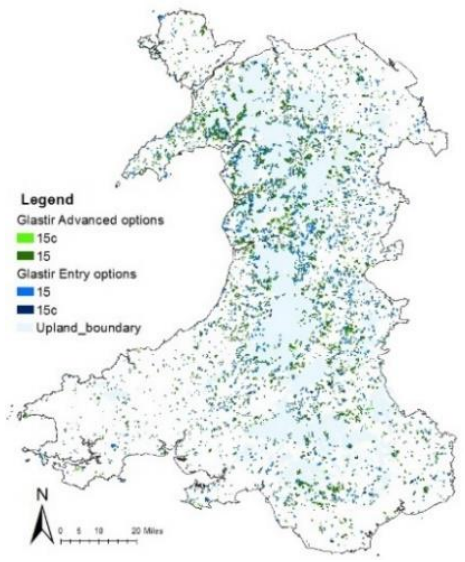

(e) Glastir - grazed pasture low inputs

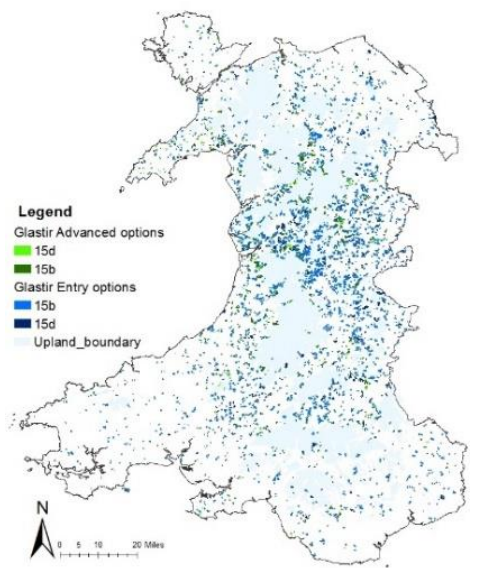

(b) GA - stock reduction option

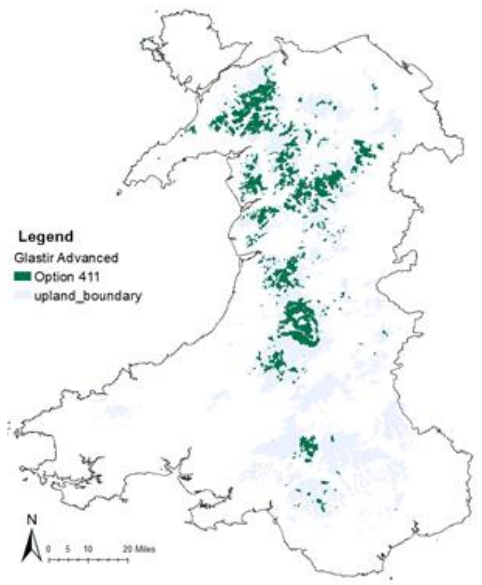

(d) GA - no nutrient input 15 Oct - 31 Jan

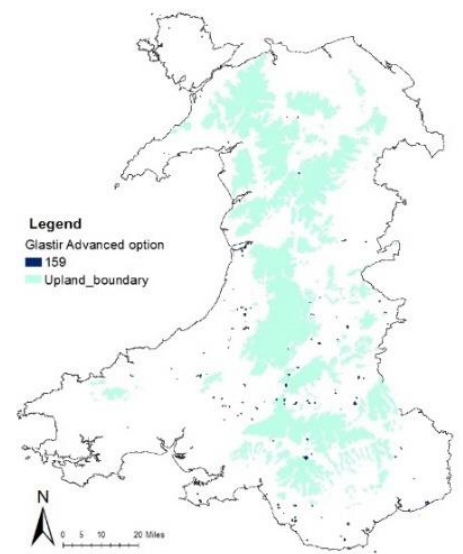

(f) Glastir - management of open country

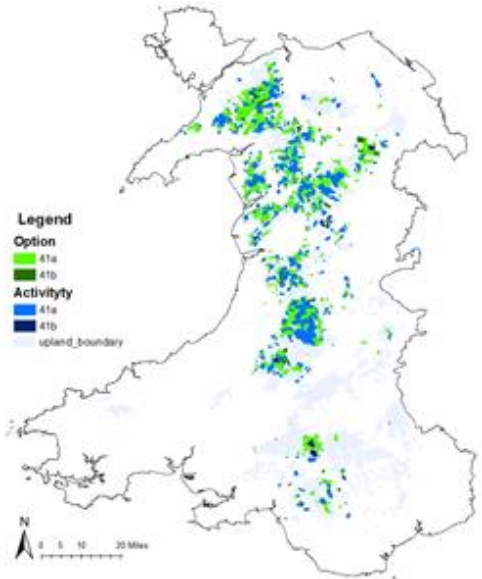

Figure 5. Habitat management by grazing and stock exclusion in 2017. (a) Stock exclusion management options for GA/GE. (b) GA stock reduction option. (c) GA/GE grazed pastures with no inputs and with no inputs and mixed grazing. (d): Stock exclusion during certain dates. (e): GA/GE grazed pasture with low inputs and with low inputs and mixed grazing. (f): GA/GE management of open country options (RPA, 2017). (c) Crown copyright / database right 2017. An Ordnance Survey / EDINA supplied service. 


\subsection{Habitat management for birds}

GA has a number of management options aimed at habitat management to promote bird populations (Fig. B6). Figure 6c shows the relatively low uptake and sparse distribution of these options at the national scale. Using lapwing (Vanellus vanellus) management options as an example, we explored distribution patterns to identify the potential effectiveness of current options. Overlaying the GA management options for lapwing onto the current lapwing distribution map (Zolnai, 2017; Fig. 6d), showed no habitat management options occurring close to the highest lapwing population areas. Conversely, it showed concentrations of option uptake in areas with no previous history of nesting lapwing populations.

\subsection{Water related management options}

Water related AES options make up only 3\% of total option uptake, and consist of options mainly targeting riparian zones through streamside corridor management, and the introduction of buffer zones (Figs. B1-2). The majority of streamside management contracts are awarded in the 'broad and shallow' GE element (Fig. 7 a). Jones et al., (2017) demonstrate that AES can deliver reductions in diffuse pollution from agriculture but scheme effectiveness is difficult to determine and effects, where detected, are not evenly distributed across the landscape. This study supports these findings by showing an uneven distribution of GA management options countrywide, with large gaps in coverage in the South East and South West. A comparison with the Water Watch Map (NRW, 2016), which provides key information relating to the Water Framework Directive (EC, 2000) river water quality classifications, (Fig. 7b), shows major gaps in management option distribution coinciding with areas with the poorest water quality. 
(a) Bracken Cover in Wales

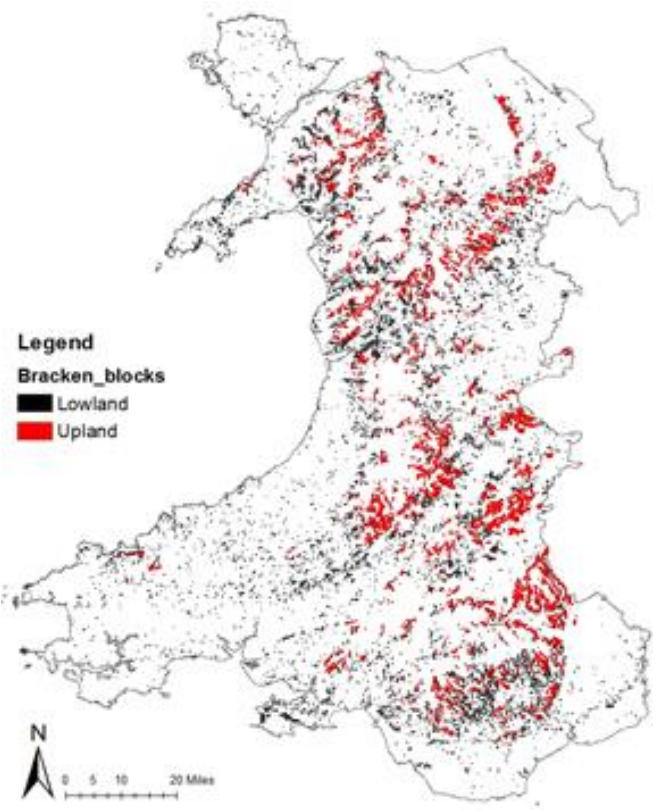

(c) GA - Habitat Management for Birds

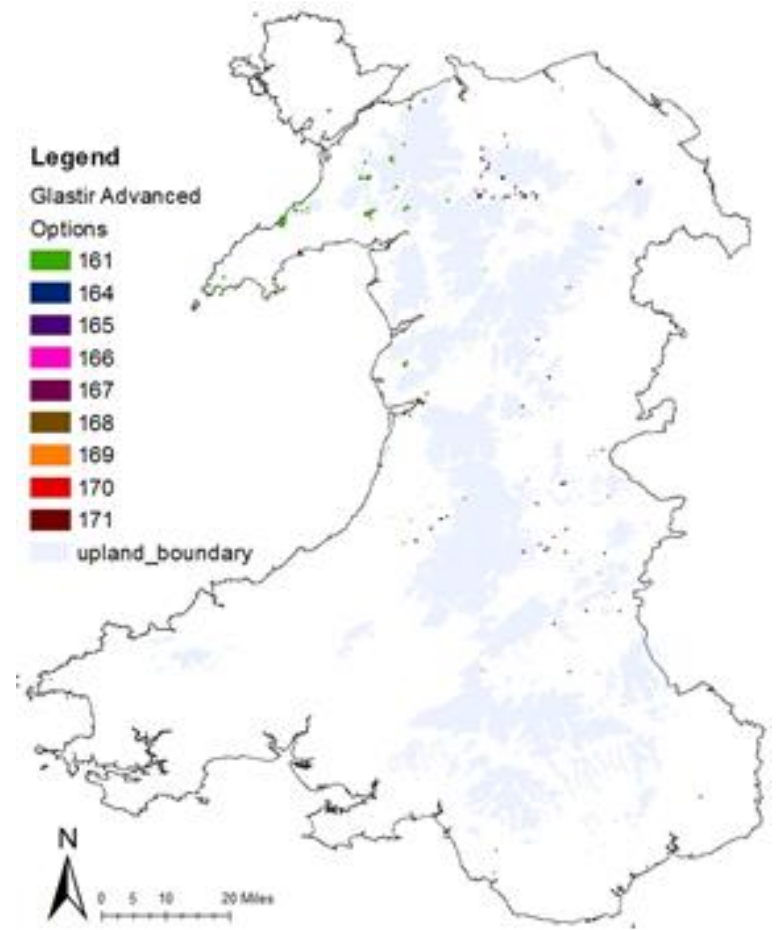

(b) Glastir - Bracken and scrub control

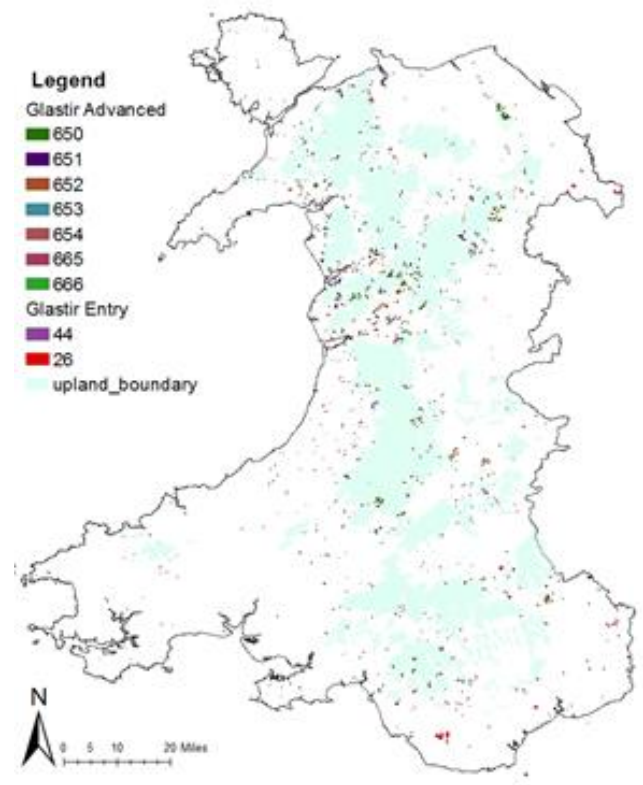

(d) Lapwing Sightings - GA lapwing options

Figure 6. Vegetation and bird management categories. (a) Bracken coverage map taken for the NRW Phase 1 terrestrial habitat data. (b) GA and GE bramble, bracken and scrub management options (Aerial, hand, mechanical and tractor delivered). (c) The distribution of GA options targeting lapwing habitat and (d) the results from the RSPB Garden Survey (2016) showing the mean sightings of lapwings Vanellus vanellus in Wales (RPA, 2017; Zolnai, 2017). "Contains Natural Resources Wales information () Natural Resources Wales and database right". (c) RSPB (c) RPA/WG (c) Crown copyright / database right 2017. An Ordnance Survey / EDINA supplied service. Ordnance Survey license number 100019741. 
(a) Glastir - Streamside Corridor Options

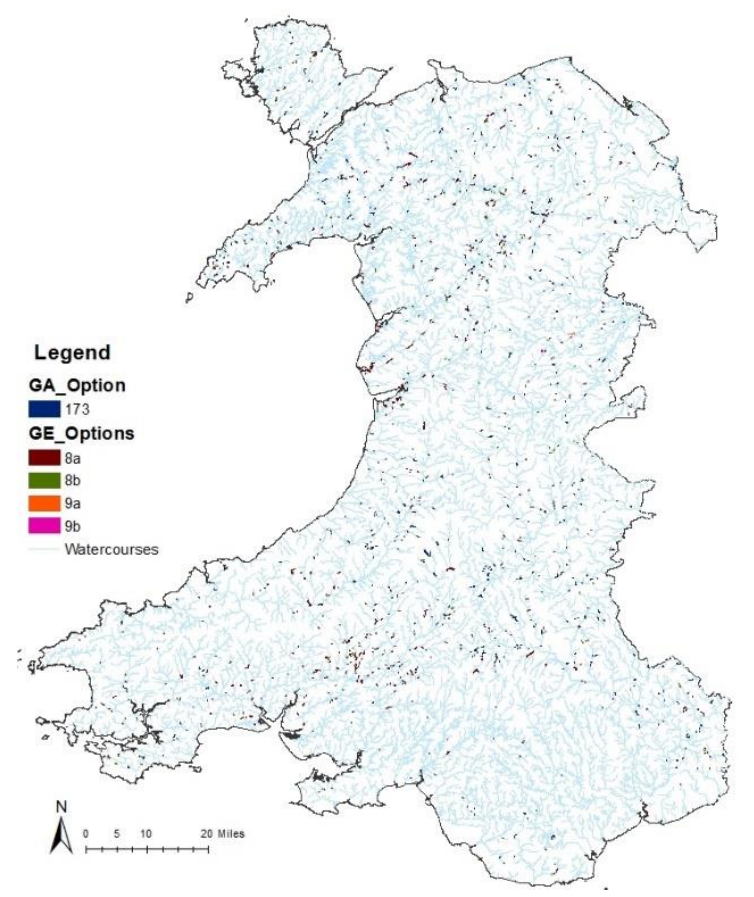

(b) Water Watch Map Wales

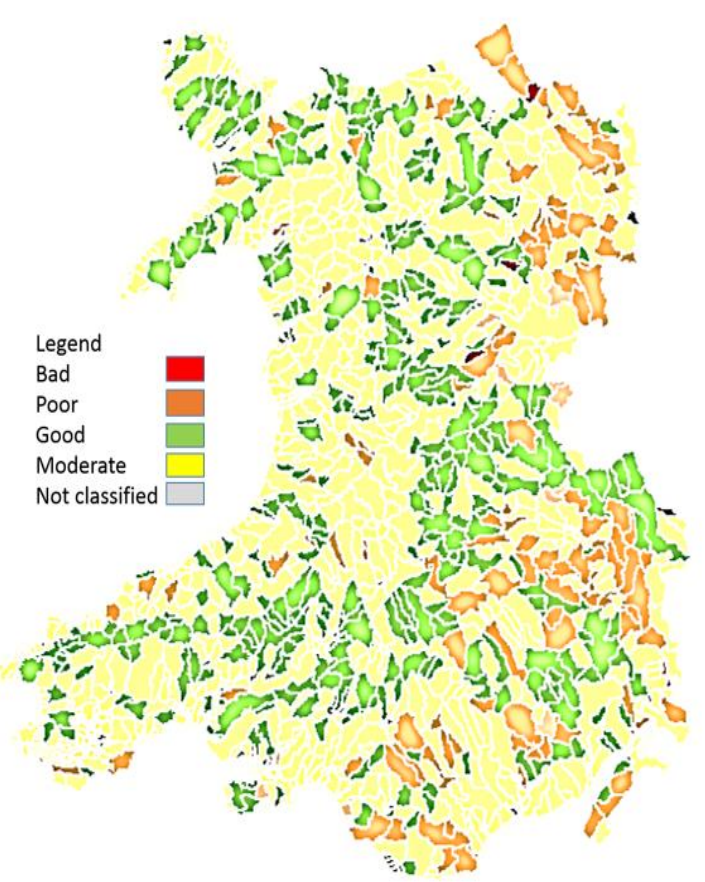

Figure 7. (a) Glastir Entry and Glastir Advanced streamside corridor management options overlaid onto the river courses of Wales (OS, Opendata, 2017). (b) The Water Watch Map of Wales - Cycle 1 Rivers and waterbodies showing the condition of the river from poor to good with an 'as yet unclassified' category (RPA, 2017; NRW, 2016b).

\section{Discussion}

\subsection{Policy and payments data}

Historically, a primary role of the CAP has been the provision of income support and social security for farmers (Helm, 2017), however, previous studies have found farms receiving greater direct payments were less efficient, on average, than other farms (Kleinhanß et al., 2007; Ferjani, 2008; Latruffe et al., 2017). Focusing on the distribution of AES funding, we show higher levels of funding in areas most suited to the delivery of ecosystem services, namely mid and north Wales. On a spatial scale, we view this distribution pattern positively, but argue that individual payment distribution patterns show, that like Pillar 1 payments (Helm, 2016), the majority of payments go to bigger and richer landowners with the majority (84\%) of recipients receiving only $35 \%$ of the total AES budget. 
It could be argued, that to achieve landscape-level impacts, funding should focus on those able to deliver AES on a large scale. We agree, but will show that in Wales the majority of recipients of AES payments deliver prescriptions on a field-scale level and argue that the prescriptive nature of the schemes means that the 957 farmers receiving $65 \%$ of the funding do not effectively deliver ecosystem services at a landscape-level. Difficulties arise in assessing the full impact of AES as habitat change is slow due to lag times in ecosystem processes (Emmett et al,. 2017), but we argue that the effectiveness of AES on a temporal scale will be significantly impaired by the spatial scale of delivery combined with the prescriptive, actionbased nature of Pillar 2 funded schemes.

Future agricultural subsidy support is likely to be linked to the provision of 'Public Goods' (Gove, 2017), which are described as goods and services with properties of non-rivalry and non-excludability (Dwyer et al., 2015), which are often under-produced, or not produced at all in the private sector (Holcombe, 1997). This means that, less favoured areas (upland habitats), with their deeply entrenched ecosystem services and goods, are likely to feature significantly in the distribution of future funding. Such habitats are the source of around $70 \%$ of the UK's drinking water, hold an estimated $40 \%$ of the UK's soil carbon, and include some of the country's most iconic cultural and aesthetic landscapes (UKNEA, 2011). The innovative ecosystem services approach, currently promoted by the Welsh Government as a delivery means, commodifies environmental goods in an attempt to counteract market failures, but it is not without challenges to its implementation (Davies-Jones, 2011; Wynne-Jones, 2013; Potter and Wolf, 2014). If policy-makers, engage farmers in scheme design (Davies-Jones, 2011), provide knowledge and skills that enhance cultural and social capital (Wynne-Jones, 2013) and overcome the methodological challenges of linking payments to outcomes (Potter and Wolf, 2014) they may be able incorporate these commodities into the production chain and hypothetically, create a 'win-win' situation, certainly in upland areas. 

economics. The CAP, through its 'greening' element and Wales, through the Well-being of Future Generations (Wales) Act 2015 (WG, 2015a), uses a multi-functional, environmentally friendly discourse to promote social, economic, environmental and cultural sustainability (Daugbjerg and Swinbank, 2016; Davies, 2016, 2017; EC, 2017). However, this sustainability discourse is not reflected in reality when it comes to funding (Erjavec and Erjavec, 2015). Agricultural subsidies are heavily skewed towards direct support payments. For example, $<15 \%$ of total agricultural support funding available in Wales is spent on AES with the remainder being spent in support of production and the development of rural communities (Defra, 2017b).

In Wales, the highest levels of AES payments are disbursed in areas rich in upland habitat, low-input farming and low farm incomes. This positive distribution pattern implies a level of targeting by the policy-makers and a willingness by farmers, in these areas, to participate in AES. Theoretically, this combination of targeted funding, suitable landscape and a willingness to participate should result in the successful delivery of "Public Goods". In reality, this combination has failed to effectively deliver results, for example, greenhouse gas (GHG) emissions from agriculture in Wales increased slightly 2009 and 2015, although they were 15\% below 1990 levels (CCC, 2017), the UK farmland bird index decreased 9\% between 2010 and 2015 (Defra, 2017c) and since 2013, the amount of farm woodland within a grant scheme has begun to decrease (WG, 2015e). In addition, the Auditor General for Wales (2014) found the Welsh Government had missed most of its targets for Glastir due to farmer participation being well below those expected by government. Where AES contracts are in place, their effectiveness is difficult to measure, partly due to a lack of measures to evaluate success (Auditor General for Wales, 2014; Jones et al., 2017). Direct subsidy removal would reduce farm household dependence on on-farm income/subsidies potentially creating externalities, 
which may be positive or negative. In New Zealand, which had a similar subsidy support system to Wales (Federated Farmers of New Zealand, 2002), sheep and beef farmers suffered severely, while for dairy, horticulture and cropping units the overall impact was generally minimal (Smith and Montgomery, 2004). Farming practices changed, dairy farming intensified and expanded dramatically whilst the sheep and beef sectors declined (Federated Farmers of New Zealand, 2002; Smith and Montgomery, 2004; Foote et al., 2015). Levels of intensification required to deliver production increases, which match subsidy loss, is likely to simultaneously increase negative environmental externalities (Foote et al., 2015). In contrast, sudden changes to the farmer's economic situation has the potential to directly impact on farm viability and increase the risk of land abandonment (Terres et al., 2015). Whilst abandonment may increase carbon sequestration (Munroe et al., 2013) and restore habitats (Keenleyside and Tucker, 2010), it also has the potential to reduce farmland biodiversity (Renwick et al., 2013), create fire risks (Moravec and Zemeckis, 2007) and impact on the cultural landscape (Navarro and Pereira, 2015). However, a shift in policy from a direct payment support system to a 'Public Money for Public Goods' approach (Gove, 2018) is likely to see upland farms in the less productive agricultural areas, more favourable to 'Public Goods' delivery, become the main beneficiaries (Helm, 2017) and that may encourage more farmers to enter AES (Lastra-Bravo et al., 2015). Financial investment which enhances farmer participation post-Brexit will help to deliver the "more" approach of Lawton et al. (2010), but significant improvements in the effectiveness of AES through the "bigger, better and joined" approach can only come through commitment to change. Governments must consider scheme design and clearly define the objectives, impact and spatial scale over which they expect schemes to deliver (Auditor General for Wales, 2014). 


\subsection{The spatial scale of scheme delivery and financial support}

The spatial scale at which an AES becomes effective is still uncertain; some studies have shown an effect at local scales (Fuentes-Montemayor et al., 2011b; Wilkinson et al., 2012), whilst others cite the main reason for AES failure being a focus at farm scale rather than the landscape scale (Whittingham, 2007; Mckenzie et al., 2013). Tscharntke et al. (2005) argue that subsidies and agri-environment incentives predominantly fund farm-scale AES operations (e.g. reduced input of agrochemicals) and this is supported by this analysis of Welsh payments that found the majority of farmers receiving total annual payments in the $£ 0-10 \mathrm{k}$ category. A recent review of the 'broad and shallow' GE scheme concluded that greater environmental benefits and better value for money could be delivered by adopting a more targeted and capitalbased approach to agri-environment support (WG, 2017f). In this study, we show some levels of connectivity between options in upland (ALC 4 and 5) landscapes but the distribution of management options across the remainder of the country appears fragmented and disconnected. With farmland constituting the single largest habitat in the UK (World Bank, 2014), the need to understand the impact of agricultural intensification, and the associated habitat fragmentation, on biodiversity (Fahrig, 2003) and the environment (Tilman, 1999) is vital if AES are to deliver successful outcomes (Tscharntke et al., 2005). The principal risk arising from investment in individual farm scale operations, without attentions to habitat matrix restoration, is that of continued isolation and fragmentation (Donald and Evans, 2006).

\subsection{Glastir options distribution and uptake}

The Natura (2000) management categories are designed to enable Wales to make significant progress towards bringing Natura 2000 species and habitats into favourable condition and help meet its commitments under the European Habitats and Birds Directives (NRW, 2015). The results of this study indicate that option distribution patterns are disproportionately biased towards habitat (excluding wildlife and bird habitat management) 
and stock management categories. These represent options that can be easily implemented by farmers, or which actually require little or no change in land management (i.e. payment with no environmental benefit). It is therefore not surprising that this bias reduces the ability of Glastir to deliver landscape level environmental outcomes for Tree, Infrastructure and Access, Water and Drainage, Wildlife, Agri-management, and Bird management categories.

\subsection{Habitat management}

The management options associated with habitat management are largely located on upland farms, with lower agricultural capacity, where farmers often adopt AES as additional sources of income to offset the risks associated with agricultural production on low productivity land (Wilson and Hart, 2000; Lastra-Bravo et al., 2015). We found the most concentrated areas of habitat management occur on acidic and calcareous grasslands where little or no agricultural improvement has occurred supporting the theory that due to lower agricultural opportunity costs, peripheral, marginal and difficult-to-farm areas are particularly likely to be enrolled in AES (Evans and Morris, 1997). Farmers often select, or apply to participate in, scheme prescriptions that fit the farm situation with low costs of compliance or minimum changes to current management practice ( Morris and Potter, 1995; Morris et al., 2000). This bias in option uptake has been identified as a primary reason why AES may fail to deliver biodiversity benefits ( Evans and Morris, 1997; Davey et al., 2010). However, the five-year contractual period binding farmers to management option delivery and the whole farm element of AES does, at the simplest level, ensure the maintenance of existing habitats on farmland and, through favourable management practices, help prevent further agricultural intensification and habitat loss (Ovenden et al., 1998).

\subsection{Livestock and vegetation management}

Glastir has two main approaches to stock management - reduction and exclusion. These approaches are arguably easier options to monitor than habitat management but they frequently 
fail to deliver the desired effect of habitat protection (Joyce, 2012; Plantlife, 2012; Mansfield, 2015). In most woodland types, species and structural diversity are higher when some browsing and grazing occurs (Hodge and Pepper, 1998). Consequently, the introduction of exclusion zones often negatively affects structural complexity and habitat diversity due to a rise in domination by weed species (Plantlife, 2012). The Welsh Government (2015b), in a selfassessment, highlighted the fact that there was no option for light grazing and that the widespread use of stock exclusion risked replacing one kind of uniformity with another. In some cases the payment for reduced stocking was being made even though heterogeneity, in the form of shorter more heavily grazed areas, would have benefitted endangered bird species such as curlew, chough and ring ouzel, leading to the need for multiple management options on the same parcel of land (WG, 2015d). Our study supports these findings by showing additional vegetation management requirements, (scrub and bracken control), occurring on the same land parcel as exclusion options. This infers a failure to achieve the desired effect through the original management approach.

GA environmental goals include GHG emission reduction, Carbon storage increases and the reversal in the decline of Wales' native biodiversity (Appendix A). Enteric fermentation $\left(\mathrm{CH}_{4}\right.$ emissions) constitute the largest component of on-farm emissions from livestock production (e.g. $~ 58 \%$, Taylor et al., 2010). The simplest approach to mitigating GHG emissions in grazed pasture systems is to reduce livestock numbers (Luo et al., 2010). Since 2012, however, sheep numbers in Wales have risen by ca. 1 million, dairy cattle have risen to 2004 levels and whilst beef cattle numbers reduced 2004 - 2016, they have since stabilised and started to increase once more. Beef cattle decreases are, most likely attributed to market forces and changes to the CAP single payment scheme (Neil, 2017). Joyce (2012) found a reduction in sheep numbers in the Cambrian Mountains but a 9-fold increase in nearby lowland areas so, whilst stock reduction options have had reduced numbers on the hill, they have had no effect 
on overall livestock numbers and consequently are expected to have little impact on net agricultural GHG emissions.

We show vegetation management options co-occur on the same land parcels as reduction and exclusion options. The removal of grazing can lead to an increase in scrub (Pollock et al., 2013), bracken (Pteridium aquilinum, Pakeman et al., 2000; Marrs et al., 2007) and Molinia (Molinia varia, Joyce, 2012). These increases represent a major invasive weed problem in agricultural grasslands (Alday et al., 2013) and are generally perceived to be bad for biodiversity (Marrs et al., 2000), with a few exceptions (Woodhouse et al., 2005). Management of these weed problems often requires intervention in the form of a vegetation control option (Ovenden et al., 1998). In the case of stock reduction and exclusion, a lack of impact assessment and defined outcomes has resulted in a failure to achieve the desired increase in biodiversity and an unnecessary doubling of payments on single land parcels.

\subsection{Management for trees}

A primary delivery mechanism to achieve strategic woodland objectives is through the GWC and GWR schemes, although both GE and GA have basic woodland management options. We have shown participation in woodland contracts in the farming community to be minimal and this is likely due to cultural barriers between farming and forestry and a lack of communication and engagement between government and the farming community (Osmond, 2012; Wynne-Jones, 2013). Where uptake has occurred a lack of impact assessment has led to cases (e.g. in the Monmouthshire and Denbighshire regions) where Glastir woodland has been inappropriately planted on species-rich semi-natural grassland (Plantlife, 2012). On a positive note, we show GWR having some effect at woodland restoration but a lack of connectivity to other woodland blocks potentially contributes to, rather than reduces, the island effect (MacArthur, and Wilson, 2001). Recent estimates, which suggest an increase in woodland cover since 2010, have been attributed to improved measurement techniques rather than 
physical increases in woodland coverage due to the success of delivery mechanisms (WG,

487 2016c).

\subsection{Management for birds}

The Royal Society for the Protection of Birds (RSPB), the UK's largest nature conservation charity, is actively involved in monitoring the effectiveness of AES in recovering farmland biodiversity across the UK (RSPB, 2017). Farmland bird populations, declining on a global scale, are widely used by policy-makers as indicators of the wider state of nature. In the US, populations of 57 of 77 (74\%) farmland-associated species decreased from 1966 to 2013 (Stanton et al., 2018); in Europe, farmland birds have fared particularly badly, with 300 million fewer birds today than in 1980 (Magalhães, et al., 2013); whilst in the UK, they are generally believed to have declined by $48 \%$ since 1970 (Robinson, et al., 2016). There is evidence that both agri-environment prescriptions and targeted conservation management, through recovery projects, can provide positive benefits to breeding Lapwing, stemming or even reversing recent population declines (Sheldon et al., 2004). However, to be successful, AES measures at field, or farm level, must be targeted and embedded within landscape level habitats managed for suitable invertebrate food sources within easy reach (Stevens and Bradbury, 2006; Dallimer et al., 2010; McHugh et al., 2017). We show management options designed to promote bird population recovery, largely fragmented and confined to farm or field scale. With the exception of a small concentration of options in North Wales, the low uptake and fragmented levels of lapwing AES interventions, used as an example in this study, may limit usefulness as a tool for population recovery (Smart et al., 2013). The RSPB 2013 Birdcount (Zolnai, 2017) and the Breeding Bird Survey 2016 (Robinson, et al., 2016) report a continued decline in various bird populations targeted by AES suggesting a lack of impact. 


\subsection{Water related management}

Riparian zones are most commonly referred to as vegetated buffer strips (e.g., riparian buffer strips) or as wildlife movement corridors (e.g. riparian corridors) (Fischer and Fischenich, 2000). Managed correctly, they can be effective in targeting a range of multiple objectives for water quality, stability, and habitat functions (Fischer and Fischenich, 2000) but recommended widths vary greatly according to the desired management outcomes (Wenger, 1999; Hawes and Smith, 2005; de Sosa et al., 2018). Simply fencing off riparian zones, may have limited effects on the conservation of farmland biodiversity (Madden et al., 2015) and, especially in the early formation stages, lead to the growth of invasive species such as Japanese Knotweed (Moore, 2018). Glastir management options stipulate that streamside corridors must be fenced off from stock, for the duration of the contract, at a minimum of $3.5 \mathrm{~m}$ from the watercourse. Narrow corridors such as these have proven effective in the short term, although long-term studies suggest the need for much wider buffers (Fischer and Fischenich, 2000; Poole et al., 2013; de Sosa et al., 2018). Once again the question of desired outcome arises. Fischer and Fischenich (2000) give recommended widths of corridors and buffer strips for vegetation, reptiles and amphibians, mammals, fish, invertebrates, birds and water quality. With the exception of one general recommendation for Detrital Input, there are no recommendations for widths less than $4 \mathrm{~m}$, raising questions on the effectiveness of a $3.5 \mathrm{~m}$ buffer strip. In Wales, there is an even distribution of AES streamside corridor management across the country, but there are still large areas of poor water quality where options are needed but have not been adopted by farmers (e.g. SW and SE Wales) (NRW, 2016). We argue that the narrow width of Glastir streamside corridors, combined with the voluntary nature of the scheme, limit the effectiveness of prescriptive AES as a water quality, management tool. It could be argued that the controlled grazing regimes of GC, and other stock reduction options, contribute to water quality management in the upland headwater areas but in the South-East 
where there are reasonably high levels of GC participation water quality is amongst the poorest

537 in the country.

\subsection{Management for biodiversity}

AES options, across all management categories, are aimed at maintaining and enhancing biodiversity (Appendix A). Current evidence differs on the effectiveness of action-based habitat options for promoting biodiversity. Interventions have been shown by some to be effective; small mammal communities on arable farmland (Broughton et al., 2014); honey bees on rural land managed under UK Higher Level AESs (Couvillon et al., 2014); hay meadows for biodiversity (Knop et al., 2006) and pollinator species richness and abundance (Albrecht et al., 2007). However, many studies have found current AES to be ineffective - no increase in herpetofaunal diversity in the short term (Michael et al., 2014); no improvement of plant biodiversity in ditch banks after a decade of agri-environment schemes (Blomqvist et al., 2009). Further, Kleijn et al. (2001) found management agreements had no positive effects on plant and bird species diversity. On balance, the evidence presented here, and elsewhere, suggests that better targeting of AES would deliver impacts that are more effective.

\subsubsection{Human, social and cultural capital}

In this study, we have discussed the complexities of option uptake and deliver through

Glastir, the Welsh government's action-based AES but one of the greatest barriers to the success of any scheme has to be a non-willingness to participate within the farming community and a lack of behavioural change. Voluntary AESs are voluntary in that participation, management options and area entered are optional (Burton et al., 2008). Methods of delivery are not voluntary, 'they do not promote any voluntary actions for environmental protection; they just force farmers to follow the standard rule' (Kaljonen, 2006). 5-year contracts require no deep personal involvement or changes in farm management strategies (de Snoo et al., 2013) and often, as a result of their prescriptive nature, do not even require farmers to learn anything 
about "good" conservation practice (Burton et al., 2008). The development of social and cultural capital is a key factor in the development of schemes which promote long-term behavioural change and foster a willingness to participate (de Krom, 2017; Burton and Paragahawewa, 2011). Result-oriented agri-environmental schemes are seen by some as a means to encourage farmer innovation in the production of environmental goods (Burton and Schwarz, 2013a) and improve AES efficiency (Sabatier et al., 2012; Schroeder et al., 2013). It is also worth considering at this point reasons for non-participation. Wilson and Hart (2000) found $49 \%(n=211)$ of interviewed farmers did not participate in AES as it 'did not fit in with their farm management plans' but, non-participation may not necessarily be through choice. Entry into a scheme may be hindered due to a lack of eligibility, through farm size or land/habitat type (Wilson, 1997; WG, 2015c).

572

\section{Conclusions and recommendations}

AES, currently embedded in EU and Welsh policies, promote 'greening', 'sustainability' and 'ecosystem services' approaches to land management. The funding structures of these policies, however, run counter to this sustainable approach, and create the first barrier to AES success, through a continued focus on productivity support. In this study, we have shown funding, scheme distribution and higher participation levels principally located on upland farms, in the less favoured areas, more favourable to 'Public Goods' delivery. Non-eligibility, a barrier to participation and therefore funding and scheme distribution, is more likely to affect lowland farmers, especially those wishing to gain access to higher-level schemes (GA), whose land may not be able to deliver the environmental benefits to levels attainable from upland habitats. This lack of eligibility may become significant in post-Brexit scheme design. Gove (2018), proposes the creation of a scheme "accessible to almost any land owner or manager who wishes to enhance the natural environment". We would argue that "almost any land 
owner" would depend on where you farm. Upland areas, may see an increase in AES

587

588

589

590

591

592

593

594

595

596

597

598

599

600

601

602

603

604

605

606

607

608

609

610

participation, an increase in scale and an increase in willingness to collaborate with others but

it is unlikely that farmers, willing to participate, but currently ineligible for higher scheme participation in lowland areas will have access to similar levels of funding. Whilst we have not discussed the possibility of 'land sparing' in this study, there is recognition that a change to policy may see the need to support 'sustainable intensification' in areas better suited to production whilst simultaneously taking land out of production in areas better suited to delivering ecosystem services (Bateman and Balmford, 2018).

A post-Brexit policy shift, could lead to an increase in the number of contiguous areas and the linking of habitats in those areas currently fragmented, but the "better and more joined" approach suggested by Lawton, et al. (2010) can only be addressed through co-ordination, and hence Government intervention. Glastir has a set of overarching objectives (Annex A) which it aims to deliver through management options but we would argue that scheme design hinders progress toward achieving these objectives. Literature clearly identifies causal relationships between prescriptions but, at a governmental level, overarching impact assessments or measurable outcomes for management options appear to be lacking. This leads to the misplacement of options, a duplication of funding within land parcels, and payments for 'business as usual' options that requires minimum change to farming practice. Whilst this approach maintains a status quo, and stops further intensification and nutrient overload, it is unlikely, through current scheme design, to significantly improve biodiversity (Davey et al., 2010), at a landscape level, or promote long-term behavioural change (de Krom, 2017). Significant improvement in the delivery of "Public Goods" requires spatial coordination of environmental management across multiple farm holdings and collaboration among governmental and other actors, including, possibly, groups of farmers (Westerink et al., 2017), clear objectives for each habitat type and impact assessments which identify the full impact of 
management options. Policy-makers must think beyond the economic aspects of AES participation (Riley et al., 2018) and invest in structures which embrace the importance of social and cultural capital, promoting peer to peer exchanges and social learning which in turn will raise the professionalism of farmer groups (Westerink et al., 2017). GC is an example of targeted scheme management requiring the formation of collaborative grazing associations to manage common land (Reed et al., 2014). Assessed to be a relatively successful part of the scheme, its good progress was attributed to the provision of Commons Development Officers (CDO) who acted as an independent interface between the farmer group and the government (Brackenbury et al., 2012; Auditor General for Wales, 2014; FCL, 2015). An understanding of needs and good communications skills enabled farmer groups to develop (FCL, 2015) whilst safeguarding the social capital within the group (Riley et al., 2018). The formation of clear objectives and outcomes potentially creates pathways to result-oriented, agri-environment schemes which are on the increase across Europe. The Burren Programme in Ireland (Burren Life Programme, 2015); the Flowering Meadows programme in France (de Sainte Marie, 2014); and the Dartmoor Farming Futures Project (Manning, 2017) are examples of schemes where participating parties receive training to be able to understand the aim of outcomes, what the outcomes should look like and what is meant by good condition. These results-based payment systems allow farmers greater freedom to decide how to manage their land (with advice, if needed) and theoretically provide the taxpayer better value for money (Burton and Schwarz, 2013b; de Sainte Marie, 2014; Burren Life Programme, 2015). Despite the potential environmental, economic and social benefits of result-oriented schemes they are not without risk to the supplier, namely the farmer (Burton and Schwarz, 2013b). Outcomes are often outwith the control of the farmer. Factors such as climate change (Westerink et al., 2008), the behaviour of neighbouring farmers (Aviron et al., 2011) and the breeding, feeding, and migration patterns of mobile species (Westerink et al., 2008) all have the potential to influence 
willingness to participate. Potential increased transaction costs and difficulties in creating

637

638

639

640

641

642

643

644

645

646

647

648

649

650

651

652

653

654

655

656

657

658

659

660

biodiversity metrics and vegetation standards means there may be situations where result-

oriented schemes are simply not effective in meeting the provision-goals (Burton and Schwarz, 2013a)

In conclusion, we show that current AES funding and scheme structures, whilst in many cases positively prevent further deterioration of existing habitat condition through a 'business as usual' approach, the voluntary, prescriptive nature of the schemes limit option uptake, the effectiveness of the scheme as a deliverer of ecosystem services, and the ability to promote long-term behavioural change. We would argue that current AES are more effective at delivering income support to ensure community and cultural cohesion and the viability of predominantly upland farming lifestyles than ecosystem services. This may of course be a government objective but if AES are to deliver "Public Goods", which meet policy demands, then targeted and adequate levels of funding, suitable landscape and a willingness to participate must be combined with greater farmer autonomy and clear outcomes to deliver management options at a landscape scale.

\section{Acknowledgements}

The authors would like to recognise the support of Gary Kingsbury of the Rural Payments Agency, Wales for his support in accessing the Glastir spatial datasets. The FLEXIS (Flexible Integrated Energy Systems) programme funded through the Welsh European Funding Office (WEFO) supported this work.

\section{References}

Albrecht, M., Duelli, P., Müller, C., Kleijn, D., Schmid, B., 2007. The Swiss agri-environment scheme enhances pollinator diversity and plant reproductive success in nearby intensively managed farmland. J. Appl. Ecol. 44, 813-822. https://doi.org/10.1111/j.13652664.2007.01306.x 
661 Alday, J.G., Cox, E.S., Pakeman, R.J., Harris, M.P.K., Leduc, M.G., Marrs, R.H., 2013. 662 Overcoming resistance and resilience of an invaded community is necessary for effective 663 restoration: A multi-site bracken control study. J. Appl. Ecol. 50, 156-167. 664 https://doi.org/10.1111/1365-2664.12015

665 Ansell, D., Freudenberger, D., Munro, N., Gibbons, P., 2016. The cost-effectiveness of agri666 environment schemes for biodiversity conservation: A quantitative review. Agric. Ecosyst. 667 Environ. 225, 184-191. https://doi.org/10.1016/j.agee.2016.04.008

668 Auditor General for Wales, 2014. Glastir. Cardiff, United Kingdom.

669

670

671

672

673

674

675

676

677

678

679

680

681

682

683

Aviron, S., Herzog, F., Klaus, I., Schüpbach, B., Jeanneret, P., 2011. Effects of wildflower strip quality, quantity, and connectivity on butterfly diversity in a Swiss arable landscape. Restor. Ecol. 19, 500-508. https://doi.org/10.1111/j.1526-100X.2010.00649.x

Banks, J., Marsden, T., 2000. Integrating agri-environment policy, farming systems and rural development: Tir Cymen in Wales. Sociol. Ruralis 40, 466-480. https://doi.org/10.1111/14679523.00161

Bateman, I.J., Balmford, B., 2018. Public funding for "Public Goods": A post-Brexit perspective on principles for agricultural policy. Land use policy 79, 293-300. https://doi.org/10.1016/j.landusepol.2018.08.022

Blomqvist, M.M., Tamis, W.L.M., de Snoo, G.R., 2009. No improvement of plant biodiversity in ditch banks after a decade of agri-environment schemes. Basic Appl. Ecol. 10, 368-378. https://doi.org/10.1016/j.baae.2008.08.007

Brackenbury, S., Short, C. J., and Lewis, N. (2012). 'Doing Things Differently: Glastir Common Land Element and the Local Action Groups': An Evaluation of the Commons Development Officer Role using the Leader Methodology. 
684

685

686

687

688

689

690

691

692

693

694

695

696

697

698

699

700

701

702

703

704

705

706

707

Broughton, R.K., Shore, R.F., Heard, M.S., Amy, S.R., Meek, W.R., Redhead, J.W., Turk, A., Pywell, R.F., 2014. Agri-environment scheme enhances small mammal diversity and abundance at the farm-scale. Agric. Ecosyst. Environ. 192, 122-129. https://doi.org/10.1016/j.agee.2014.04.009

Burren Life Programme, 2015. Burren Programme: Our Approach. [WWW Document]. http://burrenprogramme.com/the-programme/our-approach/. Accessed 04 September 2018.

Burton, R.J.F., Kuczera, C., Schwarz, G., 2008. Exploring farmers' cultural resistance to voluntary agri-environmental schemes. Sociol. Ruralis 48, 16-37. https://doi.org/10.1111/j.1467-9523.2008.00452.x

Burton, R.J.F., Paragahawewa, U.H., 2011. Creating culturally sustainable agri-environmental schemes. J. Rural Stud. 27, 95-104. https://doi.org/10.1016/j.jrurstud.2010.11.001

Burton, R.J.F., Schwarz, G., 2013a. Result-oriented agri-environmental schemes in Europe and their potential for promoting behavioural change. Land Use Policy 30, 628-641. https://doi.org/10.1016/j.landusepol.2012.05.002

Burton, R.J.F., Schwarz, G., 2013b. Result-oriented agri-environmental schemes in Europe and their potential for promoting behavioural change. Land Use Policy 30, 628-641. https://doi.org/10.1016/j.landusepol.2012.05.002

Caro, G., Marrec, R., Gauffre, B., Roncoroni, M., Augiron, S., Bretagnolle, V., 2016. Multiscale effects of agri-environment schemes on carabid beetles in intensive farmland. Agric. Ecosyst. Environ. 229, 48-56. https://doi.org/10.1016/j.agee.2016.05.009

Committee for Climate Change, 2017. Building a Low-carbon Economy in Wales. Setting Welsh Carbon Targets.

Foundation for Common Land, 2015. Pioneering Agri-environment project unites Wales's common land graziers.

[WWW Document]. 
Couvillon, M.J., Schürch, R., Ratnieks, F.L.W., 2014. Dancing bees communicate a foraging preference for rural lands in high-level agri-environment schemes. Curr. Biol. 24, 1212-1215. https://doi.org/10.1016/j.cub.2014.03.072

Dallimer, M., Gaston, K.J., Skinner, A.M.J., Hanley, N., Acs, S., Armsworth, P.R., 2010. Fieldlevel bird abundances are enhanced by landscape-scale agri-environment scheme uptake. Biol. Lett. 6, 643-646. https://doi.org/10.1098/rsbl.2010.0228

Daugbjerg, C., Swinbank, A., 2016. Three decades of policy layering and politically sustainable reform in the European Union's agricultural policy. Governance 29, 265-280. https://doi.org/10.1111/gove.12171

Davey, C., Vickery, J., Boatman, N., Chamberlain, D., Parry, H., Siriwardena, G., 2010. Assessing the impact of Environmental Stewardship on lowland farmland birds in England. Ibis (Lond. 1859). 152, 459-474. https://doi.org/10.1111/j.1474-919X.2009.01001.x

Davies-Jones, A., 2011. Implementing sustainable development for the countryside: A case study of agri-envronment reform in Wales. Environ. Law Rev. 1, 9-24. https://doi.org/10.1350/enlr.2011.13.1.110

Davies, H., 2017. The Well-being of Future Generations (Wales) Act 2015 - A step change in the legal protection of the interests of future generations? J. Environ. Law Volume 29, Pages $165-175$.

Davies, H., 2016. The Well-being of Future Generations (Wales) Act 2015. Environ. Law Rev. 18, 41-56. https://doi.org/10.1177/1461452916631889 
730 de Krom, M.P.M.M., 2017. Farmer participation in agri-environmental schemes:

731 Regionalisation and the role of bridging social capital. Land Use Policy 60, 352-361.

732 https://doi.org/10.1016/j.landusepol.2016.10.026

733 de Sainte Marie, C., 2014. Rethinking agri-environmental schemes. A result-oriented approach

734 to the management of species-rich grasslands in France. J. Environ. Plan. Manag. 57, 704-719.

735 https://doi.org/10.1080/09640568.2013.763772

736 de Snoo, G.R., Herzon, I., Staats, H., Burton, R.J.F., Schindler, S., van Dijk, J., Lokhorst, A.M.,

737 Bullock, J.M., Lobley, M., Wrbka, T., Schwarz, G., Musters, C.J.M., 2013. Toward effective

738 nature conservation on farmland: Making farmers matter. Conserv. Lett. 6, 66-72.

739 https://doi.org/10.1111/j.1755-263X.2012.00296.x

740 de Sosa, L.L., Glanville, H.C., Marshall, M.R., Abood, S.A., Williams, A.P., Jones, D.L., 2018.

741 Delineating and mapping riparian areas for ecosystem service assessment. Ecohydrology 11,

742 1-16. https://doi.org/10.1002/eco.1928

743 Defra, 2017a. Agriculture in the U.K. Department of the Environment Food and Rural Affairs.

744 Agriculture. United Kingdom.

745 Defra, 2017b. [Dataset] CAP_Payments_Data. United Kingdom.

746 Defra, 2017c. Wild Bird Populations in the UK, 1970 to 2016. Biodiversity Statistics Team,

747 Department for Environment, Food and Rural Affairs, York, United Kingdom.

748 Donald, P.F., Evans, A.D., 2006. Habitat connectivity and matrix restoration: The wider 749 implications of agri-environment schemes. J. Appl. Ecol. 43, 209-218. 750 https://doi.org/10.1111/j.1365-2664.2006.01146.x

751 Dwyer, J., 2018. The Implications of Brexit for Agriculture, Rural Areas and Land Use in 752 Wales. 
753 Ekroos, J., Olsson, O., Rundlöf, M., Wätzold, F., Smith, H.G., 2014. Optimizing agri754 environment schemes for biodiversity, ecosystem services or both? Biol. Conserv. 172, 65-71. 755 https://doi.org/10.1016/j.biocon.2014.02.013

756 Emmett B.E. and the GMEP team, 2017. Glastir monitoring and evaluation programme.

757 Erjavec, K., Erjavec, E., 2015. "Greening the CAP" - Just a fashionable justification? A 758 discourse analysis of the 2014-2020 CAP reform documents. Food Policy 51, 53-62. 759 https://doi.org/10.1016/j.foodpol.2014.12.006 ESRI, 2017. ArcGIS Desktop: ArcMap: Release 10.4.1. Redlands, CA Environ. Syst. 654 Res. I. European Commission, 2017. Proposal for a Regulation of the European Parliament and of the Council Fixing the Adjustment Rate Provided for in Regulation (EU) No 1306/2013 for direct payments in respect of the calendar year 2017.

European Commission, 2014. Commission Implementing Regulation (EU) No 908/2014 b of 766 6 August 2014 laying down rules for the application of Regulation (EU) No 1306/2013 of the European Parliament and of the Council with regard to paying agencies and other bodies, financial management 2014.

European Commission, 2013. Regulation (EU) No 1306/2013 of the European Parliament and of the Council of 17 December 2013 on the financing, management and monitoring of the common agricultural policy and repealing Council Regulations (EEC) No 352/78, (EC) No 165/94, (EC) No 2799/98 549-607.

European Commission, 2000. Directive 2000/60/EC of the European Parliament and of the Council of 23 October 2000 establishing a framework for Community action in the field of water policy. Off. J. Eur. Parliam. L327, 1-82. https://doi.org/10.1039/ap9842100196 
Evans, N.J., Morris, C., 1997. Towards a geography of agri-environmental policies in England and Wales. Geoforum 28, 189-204. https://doi.org/10.1016/S0016-7185(97)00003-1

Fahrig, L., 2003. Effects of Habitat Fragmentation on Biodiversity. Annu. Rev. Ecol. Evol. Syst. 34, 487-515. https://doi.org/10.1146/annurev.ecolsys.34.011802.132419

Federated Farmers of New Zealand, 2002. Life After Subsidies 1984-1987.

Ferjani, A. (2008). The relationship between direct payments and efficiency on Swiss farms. Agri. Econ. Rev. 9(1), 93-102.

Fischer, R. a, Fischenich, J.C., 2000. Design Recommendations for Riparian Corridors and Vegetated Buffer Strips. Development 1-17. https://doi.org/No. ERDC-TN-EMRRP-SR-24

Foote, K.J., Joy, M.K., Death, R.G., 2015. New Zealand dairy farming: Milking our environment for all its worth. Environ. Manage. 56, 709-720. https://doi.org/10.1007/s00267$015-0517-\mathrm{x}$

Fuentes-Montemayor, E., Goulson, D., Park, K.J., 2011a. Pipistrelle bats and their prey do not benefit from four widely applied agri-environment management prescriptions. Biol. Conserv. 144, 2233-2246. https://doi.org/10.1016/j.biocon.2011.05.015

Fuentes-Montemayor, E., Goulson, D., Park, K.J., 2011b. The effectiveness of agrienvironment schemes for the conservation of farmland moths: Assessing the importance of a landscape-scale management approach. J. Appl. Ecol. 48, 532-542. https://doi.org/10.1111/j.1365-2664.2010.01927.x

Gove, M., 2018. Farming for the next generation. Speech to the Oxford Farming Conference 2018. [WWW Document]. URL https://www.gov.uk/government/speeches/farming-for-thenext-generation. (accessed 17 April 2018). 
798

799

800

801

802

803

804

805

806

807

808

809

810

811

812

813

814

815

816

817

818

Gravey, V., Brown, I., Farstad, F., Hartley, S.E., Hejnowicz, A.P., Hicks, K., and Burns, C., 2017. "Post-Brexit Policy in the UK: A New Dawn? Agri-environment".

Hawes, E., Smith, M., 2005. Riparian buffer zones: Functions and recommended widths. Yale Sch. For. Enviromental Stud. 15 pp.

Helm, D., 2017. Agriculture after Brexit. Oxford Rev. Econ. Policy 33, S124-S133. https://doi.org/10.1093/oxrep/grx010

Helm, D., 2016. British Agricultural Policy after Brexit.

Johnston, M.P., 2014. Secondary data analysis: A method of which the time has Come. Qual. Methods Libr. 3, 619-626. https://doi.org/10.1097/00125817-200207000-00009

Joint Nature Conservation Committee, 2017. Area of land in agri-environment schemes.

Jones, J.I., Murphy, J.F., Anthony, S.G., Arnold, A., Blackburn, J.H., Duerdoth, C.P., Hawczak, A., Hughes, G.O., Pretty, J.L., Scarlett, P.M., Gooday, R.D., Zhang, Y.S., Fawcett, L.E., Simpson, D., Turner, A.W.B., Naden, P.S., Skates, J., 2017. Do agri-environment schemes result in improved water quality? J. Appl. Ecol. 54, 537-546. https://doi.org/10.1111/1365-2664.12780

Joyce, I.M., 2012. The Role of Grazing Animals and Agriculture in the Cambrian Mountains: Recognising Key Environmental and Economic Benefits Delivered by Agriculture in Wales' Upland.

Kaljonen, M., 2006. Co-construction of agency and environmental management. The case of agri-environmental policy implementation at Finnish farms. J. Rural Stud. 22, 205-216. https://doi.org/10.1016/j.jrurstud.2005.08.010 
819 Keenleyside, C., Tucker, G.M., 2010. Farmland abandonment in the EU: an assessment of 820 trends and prospects. Report prepared for WWF. London: Institute for European 821 Environmental Policy (IEEP).

822 Kleijn, D., Berendse, F., Smit, R., Gilissen, N., 2001. Agri-environment schemes do not 823 effectively protect biodiversity in Dutch agricultural landscapes. Nature 413, 723-725. 824 https://doi.org/10.1038/35099540

825 Kleinhanß, W., Murillo, C., San Juan, C., Sperlich, S., 2007. Efficiency, subsidies, and 826 environmental adaptation of animal farming under CAP. Agric. Econ. 36, 49-65. https://doi.org/10.1111/j.1574-0862.2007.00176.x

Knop, E., Kleijn, D., Herzog, F., Schmid, B., 2006. Effectiveness of the Swiss agrienvironment scheme in promoting biodiversity. J. Appl. Ecol. 43, 120-127. https://doi.org/10.1111/j.1365-2664.2005.01113.x

Lastra-Bravo, X.B., Hubbard, C., Garrod, G., Tolón-Becerra, A., 2015. What drives farmers' participation in EU agri-environmental schemes? Results from a qualitative meta-analysis. Environ. Sci. Policy 54, 1-9. https://doi.org/10.1016/j.envsci.2015.06.002 and technical efficiency in agriculture: Evidence from European dairy farms. Am. J. Agric. Econ. 99, 783-799. https://doi.org/10.1093/ajae/aaw077

Lawton, J.H., Brotherton, P.N.M., Brown, V.K., Elphick, C., Fitter, A.H., Forshaw, J., 838 Haddow, R.W., Hilborne, S., Leafe, R.N., Mace, G.M., Southgate, M.P., Sutherland, W.J., Tew, T.E., Varley, J., and Wynne, G.R., 2010. Making space for nature: A review of England's 840 wildlife Sites and ecological network. Rep. to Defra 107.

841 MacArthur, R. H., and Wilson, E.O., 2001. The Theory of Island Biogeography (Vol. 1). 842 Princeton university press. 
Madden, D., Harrison, S., Finn, J. A., \& Huallachain, D. O., 2015. Riparian buffer zones in intensive grassland agri-systems are not necessarily a refuge for high conservation value species. In Biology and Environment: Proceedings of the Royal Irish Academy (Vol. 115, No. 3, pp. 191-210). Royal Irish Academy.

Magalhães, M. et al., 2013. State of the World's Birds: Indicators for our changing world. Biol.

Conserv. 1, 28. https://doi.org/10.1126/science.1187512

Manning, J., 2017. Dartmoor Farming Futures: [WWW Document]. Evaluation Report.

Report.pdf. (accessed 04/09/18).

Mansfield, L., 2015. Upland farming systems and wilding landscapes: a Cumbrian example.

Wild Thing Conference in Sheffield, UK. 9-11 September 2015. Wild Thing? Manag. Landsc.

Chang. Futur. Ecol. 1-18.

Marrs, R.H., Galtress, K., Tong, C., Cox, E.S., Blackbird, S.J., Heyes, T.J., Pakeman, R.J., Le

Duc, M.G., 2007. Competing conservation goals, biodiversity or ecosystem services: Element losses and species recruitment in a managed moorland-bracken model system. J. Environ. Manage. 85, 1034-1047. https://doi.org/10.1016/j.jenvman.2006.11.011

Marrs, R.H., Le Duc, M.G., Mitchell, R.J., Goddard, D., Paterson, S., Pakeman, R.J., 2000.

The ecology of bracken: Its role succession and implications for control. Ann. Bot. 85, 3-15. https://doi.org/10.1006/anbo.1999.1054

McHugh, N.M., Goodwin, C.E.D., Hughes, S., Leather, S.R., Holland, J.M., 2016. Agri- 

measures and the breeding ecology of a declining farmland bird. Biol. Conserv. 212, 230-239. https://doi.org/10.1016/j.biocon.2017.06.023

Mckenzie, A.J., Emery, S.B., Franks, J.R., Whittingham, M.J., 2013. FORUM: Landscapescale conservation: Collaborative agri-environment schemes could benefit both biodiversity and ecosystem services, but will farmers be willing to participate? J. Appl. Ecol. 50, 12741280. https://doi.org/10.1111/1365-2664.12122

Michael, D.R., Wood, J.T., Crane, M., Montague-Drake, R., Lindenmayer, D.B., 2014. How

effective are agri-environment schemes for protecting and improving herpetofaunal diversity in Australian endangered woodland ecosystems? J. Appl. Ecol. 51, 494-504. https://doi.org/10.1111/1365-2664.12215.

Moore, C., 2018. Riparian Buffers and Invasive Species. Stream of Consciousness, 26.

Moravec, J., and Zemeckis, R., 2007. Cross compliance and land abandonment. A Res. Pap. Cross-Compliance Netw. (Contract Eur. Community's Sixth Framew. Program. SSPE-CT2005-022727), Deliv. D17 Cross-Compliance Network.

Morris, C., Potter, C., 1995. Recruiting the new conservationists: Farmers' adoption of agrienvironmental schemes in the U.K. J. Rural Stud. 11, 51-63. https://doi.org/10.1016/07430167(94)00037-A

Morris, J., Mills, J., Crawford, I.M., 2000. Promoting farmer uptake of agri-environment schemes: The Countryside Stewardship Arable Options Scheme. Land Use Policy 17, 241254. https://doi.org/10.1016/S0264-8377(00)00021-1 
889 National Audit Office, 2017. A Short Guide to the Department for Environment, Food and 890 Rural Affairs.

891 Natural England, 2018. Assessing the Contribution of Agri-environment Schemes to Climate 892 Change Adaptation.

893 Natural Resources Wales, 2016. Water Watch Wales [WWW Document]. URL 894 http://waterwatchwales.naturalresourceswales.gov.uk/en/ (Accessed 05 December 780\%0A $895 \% 0$ A2017).

896 Natural Resources Wales, 2015. Natura 2000 in Wales: Costings for Terrestrial Actions Natura 8972000 yng Nghymru : Costings for Terrestrial Actions 1-30.

898 899 900 901

Natural Resources Wales, 2014. Registered Common Lands. Ordnance Survey Data. Ordnance Survey Licence number 100019741. Crown Copyright Database.

Navarro, L. M., and Pereira, H.M., 2015. Rewilding abandoned landscapes in Europe. Rewilding Eur. Landscapes (pp. 3-23). Springer, Cham.

Osmond, J., 2012. Growing our Woodlands in Wales 1-10.

Ovenden, G.N., Swash, A.R.., Smallshire, D., 1998. Agri-environment schemes and their contribution to the conservation of biodiversity in England. J. Appl. Ecol. 35, 955-960. https://doi.org/10.1111/j.1365-2664.1998.tb00014.x

Pakeman, R.J., Le Duc, M.G., Marrs, R.H., 2000. Bracken distribution in Great Britain: Strategies for its control and the sustainable management of marginal land. Ann. Bot. 85, 3746. https://doi.org/10.1006/anbo.1999.1053

Plantlife, 2012. Forestry Recommissioned: Revitalising the Woodlands of Wales.

Pollock, M.L., Holland, J.P., Morgan-Davies, C., Morgan-Davies, J., Waterhouse, A., 2013. Reduced sheep grazing and biodiversity: A novel approach to selecting and measuring 

$11-00123.1$

914

Poole, A.E., Bradley, D., Salazar, R., Macdonald, D.W., 2013. Optimizing agri-environment schemes to improve river health and conservation value. Agric. Ecosyst. Environ. 181, 157168. https://doi.org/10.1016/j.agee.2013.09.015

Potter, C., Wolf, S.A., 2014. Payments for ecosystem services in relation to US and UK agrienvironmental policy: Disruptive neoliberal innovation or ... policy adaptation? Office of Environmental Markets. https://doi.org/10.1007/s10460-014-9518-2

Princé, K., Moussus, J.P., Jiguet, F., 2012. Mixed effectiveness of French agri-environment schemes for nationwide farmland bird conservation. Agric. Ecosyst. Environ. 149, 74-79. https://doi.org/10.1016/j.agee.2011.11.021

Reed, M.S., Moxey, A., Prager, K., Hanley, N., Skates, J., Bonn, A., Evans, C.D., Glenk, K., Thomson, K., 2014. Improving the link between payments and the provision of ecosystem services in agri-environment schemes. Ecosyst. Serv. 9, 44-53. https://doi.org/10.1016/j.ecoser.2014.06.008 D., 2013. Policy reform and agricultural land abandonment in the EU. Land Use Policy 30, 446-457. https://doi.org/10.1016/j.landusepol.2012.04.005

Riley, M., Sangster, H., Smith, H., Chiverrell, R., Boyle, J., 2018. Will farmers work together for conservation? The potential limits of farmers' cooperation in agri-environment measures. Land Use Policy 70, 635-646. https://doi.org/10.1016/j.landusepol.2017.10.049 
R.H. and Baillie, S.R., 2016. BirdTrends 2016: Trends in Numbers, Breeding Success and Survival for UK Breeding Birds. Thetford.

937

Rose, H. (2011). An introduction to Glastir and other UK agri-environment schemes. Members

Research Service, National Assembly of Wales Commission. http://www. assemblywales. org/11-012. pdf (accessed 04/09/2018).

940

[dataset] Rural Payments Wales, 2017. Glastir Options. Released under licence from Rural Payments Agency.

Russi, D., Margue, H., Oppermann, R., Keenleyside, C., 2016. Result-based agri-environment measures: Market-based instruments, incentives or rewards? The case of Baden-Württemberg. Land Use Policy 54, 69-77. https://doi.org/10.1016/j.landusepol.2016.01.012

Sabatier, R., Doyen, L., Tichit, M., 2012. Action versus result-oriented schemes in a Grassland agroecosystem: A dynamic modelling approach. PLoS One 7. https://doi.org/10.1371/journal.pone.0033257

Schroeder, L.A., Isselstein, J., Chaplin, S., Peel, S., 2013. Agri-environment schemes: Farmers' acceptance and perception of potential "Payment by Results" in grassland-A case study in England. Land Use Policy 32, 134-144. https://doi.org/10.1016/j.landusepol.2012.10.009

Sheldon, R., Bolton, M., Gillings, S., Wilson, A., 2004. Conservation management of Lapwing Vanellus vanellus on lowland arable farmland in the UK. Ibis (Lond. 1859). 146, 41-49. https://doi.org/10.1111/j.1474-919X.2004.00365.x

Smart, J., Bolton, M., Hunter, F., Quayle, H., Thomas, G., Gregory, R.D., 2013. Managing uplands for biodiversity: Do agri-environment schemes deliver benefits for breeding lapwing Vanellus vanellus? J. Appl. Ecol. 50, 794-804. https://doi.org/10.1111/1365-2664.12081

957 Smith, W., Montgomery, H., 2004. Revolution or evolution? New Zealand agriculture since 1984. GeoJournal 59, 107-118. https://doi.org/10.1023/B:GEJO.0000019969.38496.82 
Stanton, R.L., Morrissey, C.A., Clark, R.G., 2018. Analysis of trends and agricultural drivers of farmland bird declines in North America: A review. Agric. Ecosyst. Environ. 254, 244-254. https://doi.org/10.1016/j.agee.2017.11.028

962

Stevens, D.K., Bradbury, R.B., 2006. Effects of the Arable Stewardship Pilot Scheme on breeding birds at field and farm-scales. Agric. Ecosyst. Environ. 112, 283-290. https://doi.org/10.1016/j.agee.2005.07.008

Terres, J.M., Scacchiafichi, L.N., Wania, A., Ambar, M., Anguiano, E., Buckwell, A., Coppola, 966 A., Gocht, A., Källström, H.N., Pointereau, P., Strijker, D., Visek, L., Vranken, L., Zobena, A., 2015. Farmland abandonment in Europe: Identification of drivers and indicators, and development of a composite indicator of risk. Land Use Policy 49, 20-34. https://doi.org/10.1016/j.landusepol.2015.06.009

Tilman, D., 1999. Global environmental impacts of agricultural expansion: the need for sustainable and efficient practices. Proc. Natl. Acad. Sci. U. S. A. 96, 5995-6000. https://doi.org/10.1073/pnas.96.11.5995

Tscharntke, T., Klein, A.M., Kruess, A., Steffan-Dewenter, I., Thies, C., 2005. Landscape perspectives on agricultural intensification and biodiversity - Ecosystem service management. Ecol. Lett. 8, 857-874. https://doi.org/10.1111/j.1461-0248.2005.00782.x

UK National Ecosystem Assesment, 2011. UK National Ecosystem Assessment Synthesis of the Key Findings. Unep-Wcmc Cambridge, 87. https://doi.org/10.1177/004057368303900411

Welsh Government, 2018. Brexit and our land: Securing the future of Welsh farming. Cardiff, United Kingdom. 
Welsh Government, 2017d. United Kingdom - Rural Development Programme (2014-2020)

985 (Regional) - Wales. Cardiff, United Kingdom.

986

Welsh Government, 2017e. Predictive Agricultural Land Classification (ALC) Map. [WWW 987 Document]. http://lle.gov.wales/map/alc. (Accessed 04/09/18).

Welsh Government, 2017f. United Kingdom - Rural Development Programme (2014-2020) (Regional) - Wales 77.

Welsh Government, 2017g. Personal Communication. Agriculture - Sustainability 991 development division. Cardiff, United Kingdom.

992

Welsh Government, 2016a. Environment (Wales) Act 2016. Cardiff, United Kingdom.

Welsh Government, 2016b. Woodlands for Wales Action Plan. Cardiff, United Kingdom.

Welsh Government, 2016c. Woodlands for Wales Indicators 2015-16. [WWW Document]. 04/09/18).

997

Welsh Government, 2015a. Well-being of Future Generations Act (Wales). Cardiff, United 998 Kingdom.

999

Welsh Government, 2015b. Glastir Entry Booklet 1: General Guidance 2015. [WWW Document]. https://beta.gov.wales/sites/default/files/publications/2018-01/glastir-entry-20151001 rules-booklet-1.pdf. (accessed 04/09/18).

1002 Welsh Government, 2015c. Glastir Advanced. [WWW Document]. 1003 https://gov.wales/docs/drah/publications/170217-glastir-advanced-2018-expression-ofinterest-rules-booklet1-en.pdf. (Accessed 04/09/18). 
1005 Welsh Government, 2015d. Glastir Advanced Evaluation Panel Findings and 1006 Recommendations $\quad$ [WWW $1-32 . \quad$ Document]. 1007 https://gov.wales/docs/drah/publications/150604-glastir-advanced-evaluation-panel-findings1008 recommendations-en.pdf. (Accessed 04/09/18).

1009 Welsh Government, 2015e. Woodlands for Wales Indicators. [WWW Document]. 1010 https://gov.wales/statistics-and-research/woodlands-wales-indicators/?lang=en. (Accessed $101104 / 09 / 18)$.

1012 Welsh Government, 2012. Written Statement - Glastir update. [WWW Document]. 1013 https://gov.wales/about/cabinet/cabinetstatements/previous-

1014 administration/2013/glastir/?lang=en. (Accessed 04/09/18).

1015 Welsh Government, 2010. Climate Change Strategy for Wales. [WWW Document]. 1016 https://gov.wales/docs/desh/publications/101006ccstratfinalen.pdf. (Accessed 04/09/18).

1017 Wenger, S., 1999. A review of the scientific literature on riparian buffer width, extent and 1018 vegetation, Soil Science Society of America Journal. https://doi.org/30602-2202

1019 Westerink, J., Buizer, M., Santiago Ramos, J., 2008. European lessons for green and blue 1020 services in the Netherlands. Nature 1-26.

1021 Westerink, J., Jongeneel, R., Polman, N., Prager, K., Franks, J., Dupraz, P., Mettepenningen, 1022 E., 2017. Collaborative governance arrangements to deliver spatially coordinated agri1023 environmental management. Land Use Policy 69, 176-192. 1024 https://doi.org/10.1016/j.landusepol.2017.09.002

1025 Whittingham, M.J., 2007. Will agri-environment schemes deliver substantial biodiversity gain, and if not why not? J. Appl. Ecol. 44, 1-5. https://doi.org/10.1111/j.1365-2664.2006.01263.x 
1040

1041

1042

1043

1044

1045

1046

1047

1048

Wilkinson, N.I., Wilson, J.D., Anderson, G.Q.A., 2012. Agri-environment management for corncrake Crex crex delivers higher species richness and abundance across other taxonomic groups. Agric. Ecosyst. Environ. 155, 27-34. https://doi.org/10.1016/j.agee.2012.03.007

Wilson, G., 1997. Factors influencing farmer participation in the Environmentally Sensitive Areas Scheme. J. Environ. Manage. 50, 67-93.

Wilson, G.A., Hart, K., 2000. Financial imperative or conservation concern? EU farmers' motivations for participation in voluntary agri-environmental schemes. Environ. Plan. A 32, 2161-2185. https://doi.org/10.1068/a3311

Wood, T.J., Holland, J.M., Hughes, W.O.H., Goulson, D., 2015. Targeted agri-environment schemes significantly improve the population size of common farmland bumblebee species. Mol. Ecol. 24, 1668-1680. https://doi.org/10.1111/mec.13144

Woodhouse, S.P., Good, J.E.G., Lovett, A.A., Fuller, R.J., Dolman, P.M., 2005. Effects of land-use and agricultural management on birds of marginal farmland: A case study in the Llŷn peninsula, Wales. Agric. Ecosyst. Environ. 107, 331-340. https://doi.org/10.1016/j.agee.2004.12.006

World Bank, 2014. Agricultural land (\% of land area). [WWW Document]. URL https://data.worldbank.org/indicator/AG.LND.AGRI.ZS?locations=GB. (Accessed 30/08/18).

Wynne-Jones, S., 2013. Carbon blinkers and policy blindness: The difficulties of "Growing Our Woodland in Wales." Land Use Policy 32, 250-260. https://doi.org/10.1016/j.landusepol.2012.10.012

Zolnai, A., 2017. RSPB2013 Birdcount Map, [Dataset]. [WWW Document]. https://doi.org/http://dx.doi.org/10.7488/ds/1917. 
1051

1052

1053

1054

1055

1056

1057

1058

1059

1060

1061

1062

1063

1064

1065

1066

1067

1068

1069

1070

Appendix A: The Glastir AES Scheme (Rose, 2011) and the Welsh Land Classification System (WG, 2017e).

\section{Structure.}

Glastir pays for the delivery of specific environmental goods and services aimed at:

- Combating climate change.

- Improving water management.

- Maintaining and enhancing biodiversity.

2. Glastir Advanced - scheme closed to new entrants.

Glastir Advanced is a five-year whole farm sustainable land management commitment designed to deliver the following environmental aims:

- Reducing carbon and greenhouse gas emissions.

- Adapting to climate change and building greater resilience into farm businesses.

- Managing our water resources to improve water quality and reduce flood risks.

- Contributing to economic sustainability of farms and the wider rural community.

- Protecting the landscape and the historic environment while improving access.

- Contributing towards a reversal in the decline of Wales' native biodiversity.

\section{Glastir Commons - scheme closed to new entrants.}

Common land forms an important element of the farming tradition in Wales, particularly as a grazing resource.

It also plays a key role in the management of habitats and the Welsh landscape.

\subsection{Options}

There were two options under Glastir Commons: 
- A closed period of 3 continuous months in a 5 month period between November and March, or

- Minimum and maximum stocking densities tailored to each common with monthly diaries kept to record the movement of stock.

\section{Glastir Efficiency Grants - scheme closed to new entrants.}

A capital grant scheme aimed at improving resource and business efficiency, and reducing the carbon equivalent emissions of agricultural and horticultural holdings.

\section{Glastir Entry - scheme closed to new applicants.}

Glastir Entry was a whole farm, land management scheme open to all farmers and land managers throughout Wales. Successful applicants made a commitment to deliver environmental goods for five years under a legally binding contract.

5.1. The All Wales Element was comprised of 3 main components:

- Cross compliance - a set of compulsory requirements applied to all your agricultural land.

- The Whole Farm Code (WFC) - this applied to all the land entered into the contract

- Management options - you were able to select from a range of options that were best suited to your farm. A minimum number of options were required in order to reach your points threshold.

\section{Glastir Organic - scheme closed to new entrants.}

Glastir Organic was an element of the Welsh Government's Glastir Scheme. Glastir Organic provided support to organic farmers and producers, who delivered positive environmental land management.

6.1. Glastir Organic was a 5-year contract with Welsh Government, open to:

- Those who wished to convert to organic production. 
- Existing organic producers who met the eligibility criteria.

1098

\section{Glastir Small Grants.}

Land Managers and Farming Businesses across Wales have an opportunity to apply for Capital Works under the Glastir Small Grants Scheme.

This stand-alone scheme contributes to the delivery of Welsh Government's ambitions to tackle climate change, improve water management, restore traditional landscape features and enhance habitat linkage for pollinators.

7.1. There are three themes under Glastir Small Grants:

- Carbon - aid the delivery of Welsh Government's ambitions to increase carbon sequestration.

- Water - improve water quality and reduce the risk of flooding.

- Landscape and Pollinators - maintain the traditional landscape features in Wales, and provide habitat linkage for pollinating insects.

\section{Glastir Woodland Creation.}

Glastir Woodland Creation provides financial support for new planting. Financial support is also available for planting trees in areas that continue to be grazed as part of an agroforestry system i.e. combining agriculture and forestry.

\section{Glastir Woodland Restoration.}

Funding is available to replant areas of larch that have been felled to help prevent the spread of Phytophthora ramorum disease affecting the trees.

The area eligible for funding under Glastir Woodland Restoration will be equivalent to twice the area of larch identified on the Statutory Plant Health Notice or felling licence. For example, if 1 hectare of larch is shown on your felling licence, the maximum area eligible for funding under Glastir Restoration will be 2 hectares. 


\section{Post code areas.}

The HR postcode district was excluded for the purpose of this research as it size, and location on the Wales/England border, makes it difficult to distinguish between payments being made to Welsh farmers with land in England or English Farmers with land in Wales.

\section{Land Parcel Identification System (LPIS).}

An IT system based on photographs of agricultural parcels used to check payments made under the Common Agricultural Policy (CAP).

12. Generalised Description of the Agricultural Land Classification Grades Grade and standard colour notations Description of agricultural land Detail (WG, 2017e).

Grade 1: Excellent quality No or very minor limitations on agricultural use. Wide range of agricultural and horticultural crops can be grown. High yielding and consistent.

Grade 2: Very good Minor Limitations on crop yield, cultivations or harvesting. Wide range of crops but limitations on demanding crops (e.g. winter harvested veg). Yield high but lower than Grade 1.

Grade 3: (subdivided) Good to moderate Moderate limitations on crop choice, timing and type of cultivation, harvesting or level of yield. Yields lower and more variable than Grade 2.

Grade 3a: Good Moderate to high yields of narrow range of arable crops (e.g. cereals), or moderate yields of grass, oilseed rape, potatoes, sugar beet and less demanding horticultural crops. $3 b$ Moderate Moderate yields of cereals, grass and lower yields other crops. High yields of grass for grazing/ harvesting.

Grade 4: Poor Severe limitations which restrict range and/or level of yields. Mostly grass and occasional arable (cereals and forage), but highly variable yields. Very droughty arable land included. 

grazing except for pioneering forage crops.

Appendix B: The breakdown of Glastir management categories (RPA, 2017)

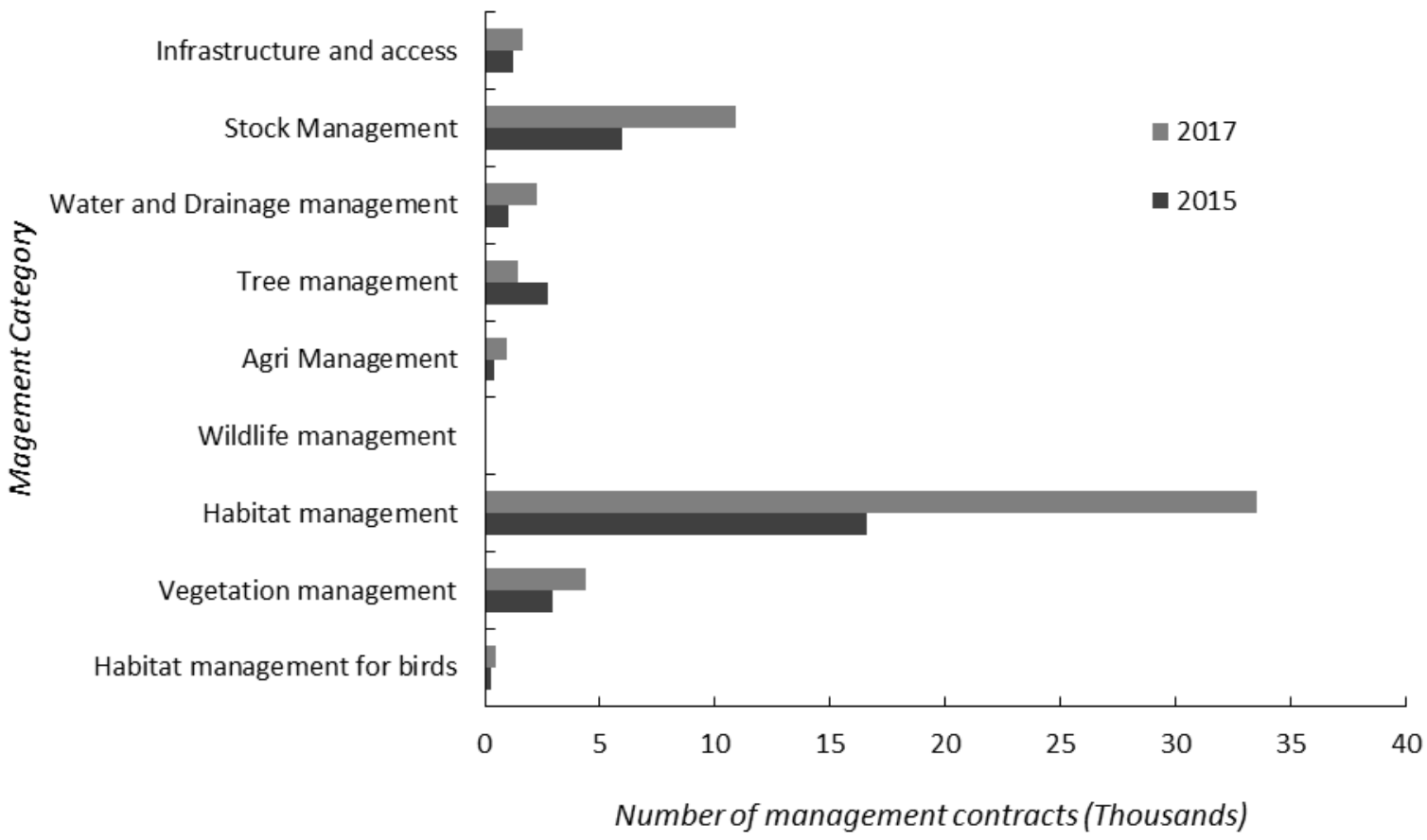

Figure B.1. Total GA management contracts by management categories for 2015 and 2017 (RPA, 2017).

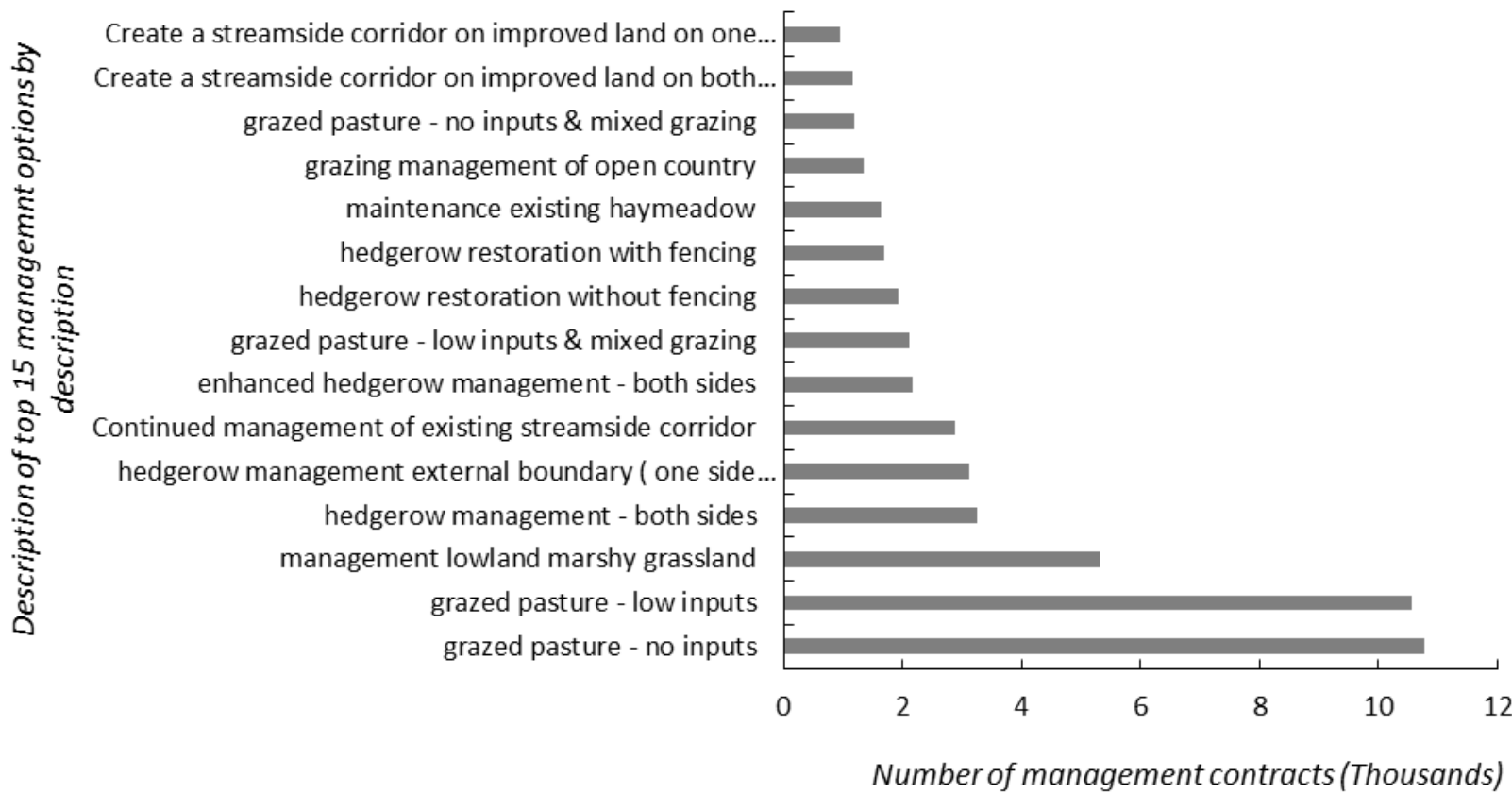


Grassland managed with no inputs between 15 October.. Lowland unimproved acid grassland Bracken Control - Mechanical Two Cuts/Yr Scrub Clearance - hand Enhanced hedgerow management - both sides Maintenance existing haymeadow Hard Surfacing Streamside corridor management grazing management of open country Additional Management Payment - Reduce stocking grazed pasture - low inputs management lowland marshy grassland Lowland marshy grassland Woodland - stock exclusion Grazed pasture - no inputs

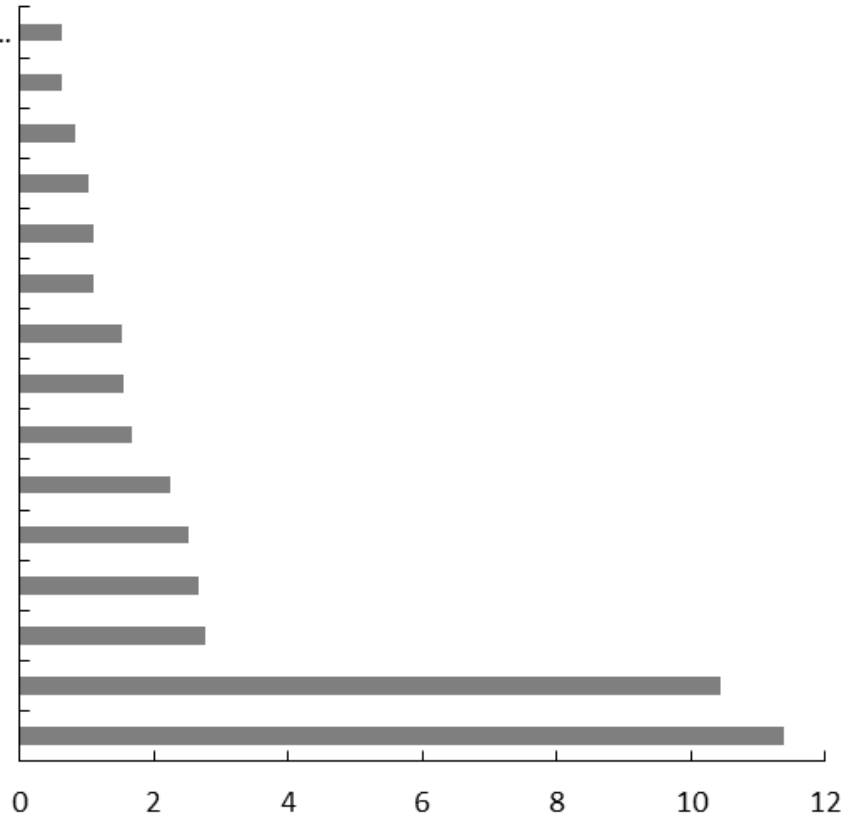

Number of management contracts (Thousands)

Figure B.38. Top 15 GA management options for 2017 by number of management contracts (RPA, 2017).

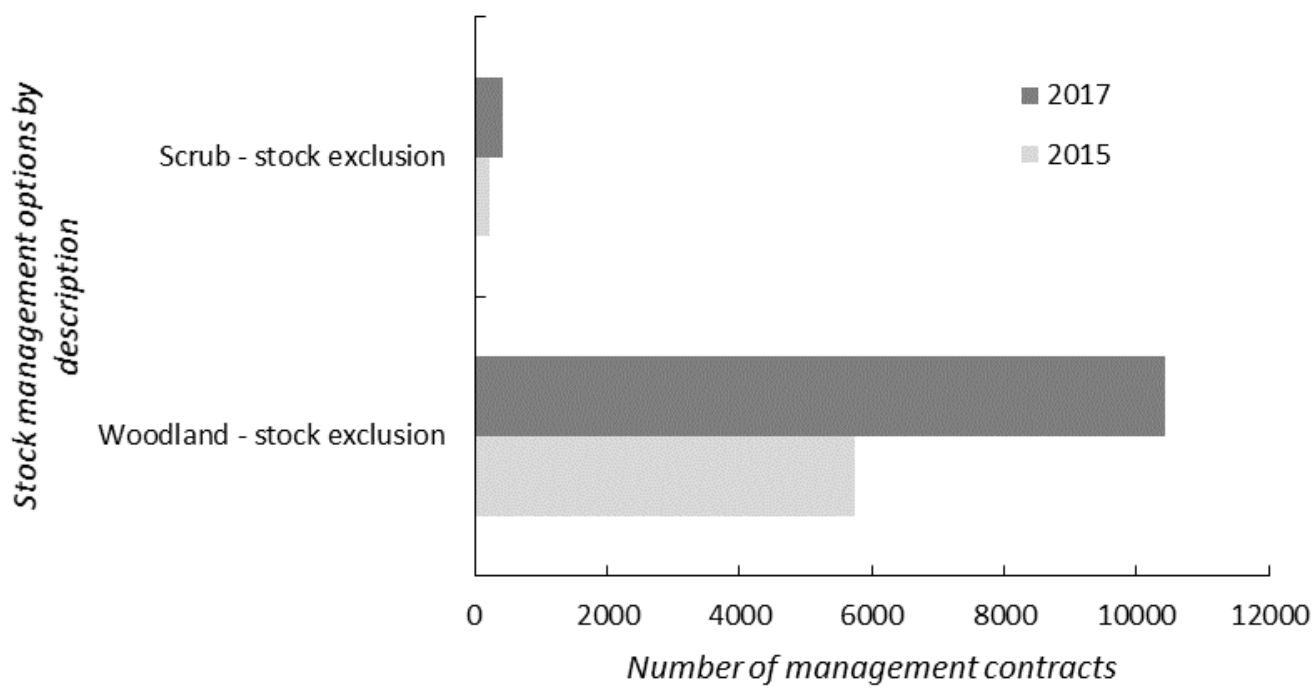




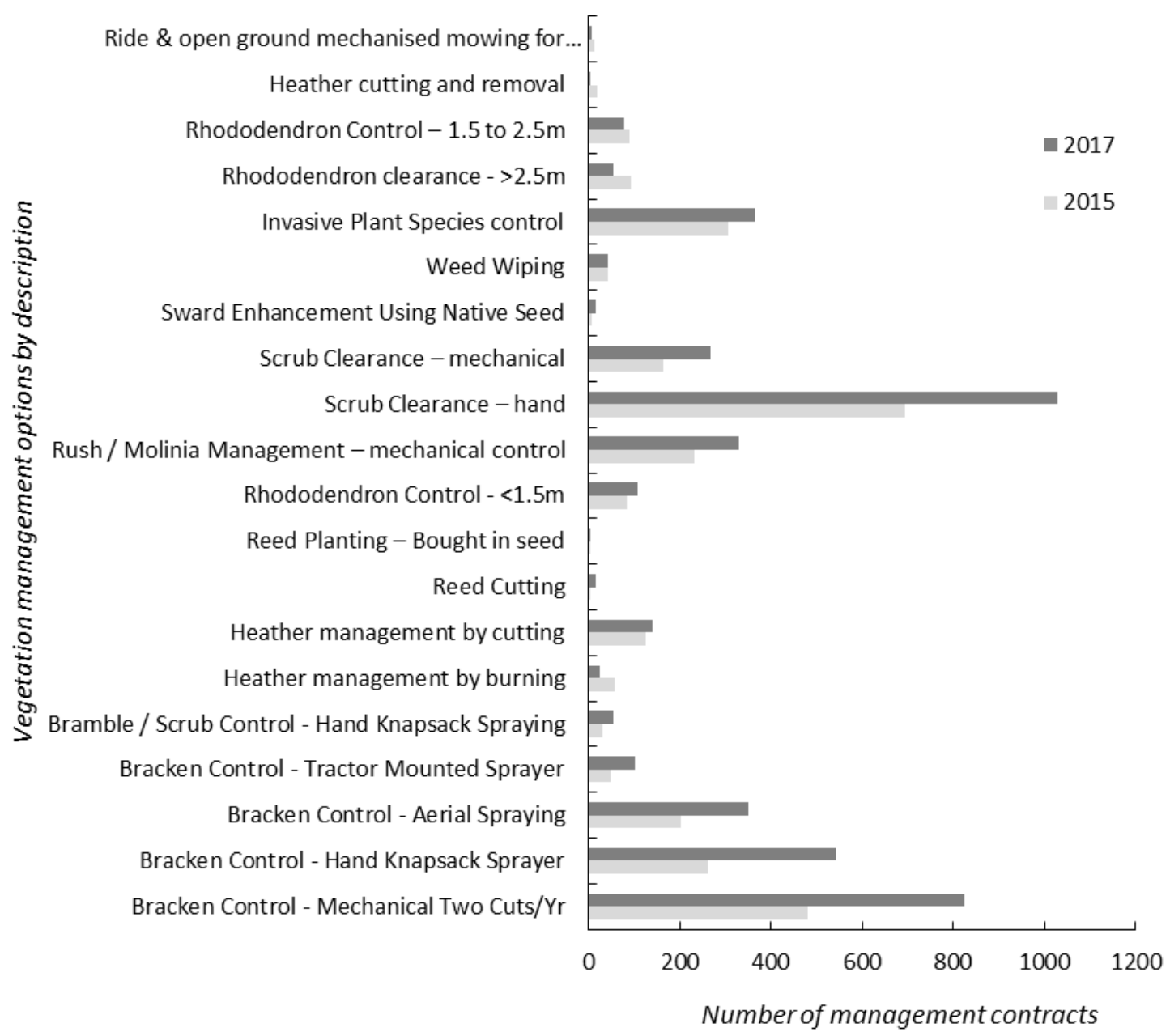

1161

Figure B.59. GA vegetation management options for 2015 and 2017 by number of contracts (RPA, 2017).

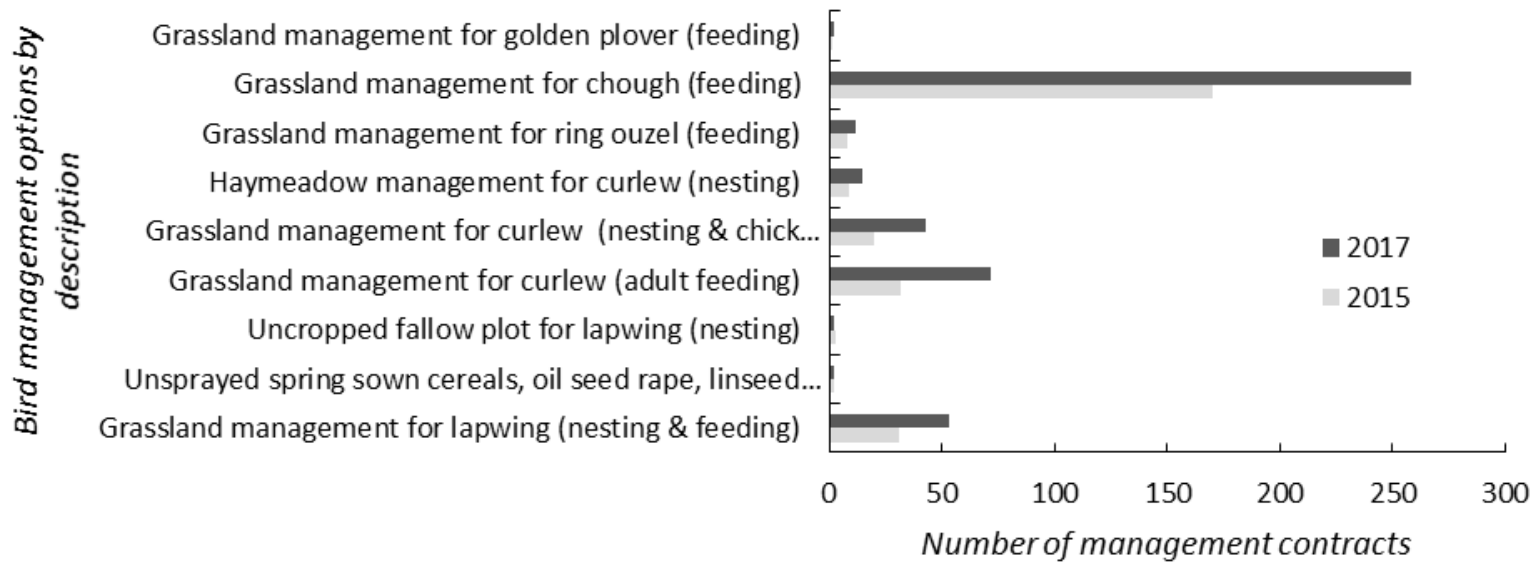



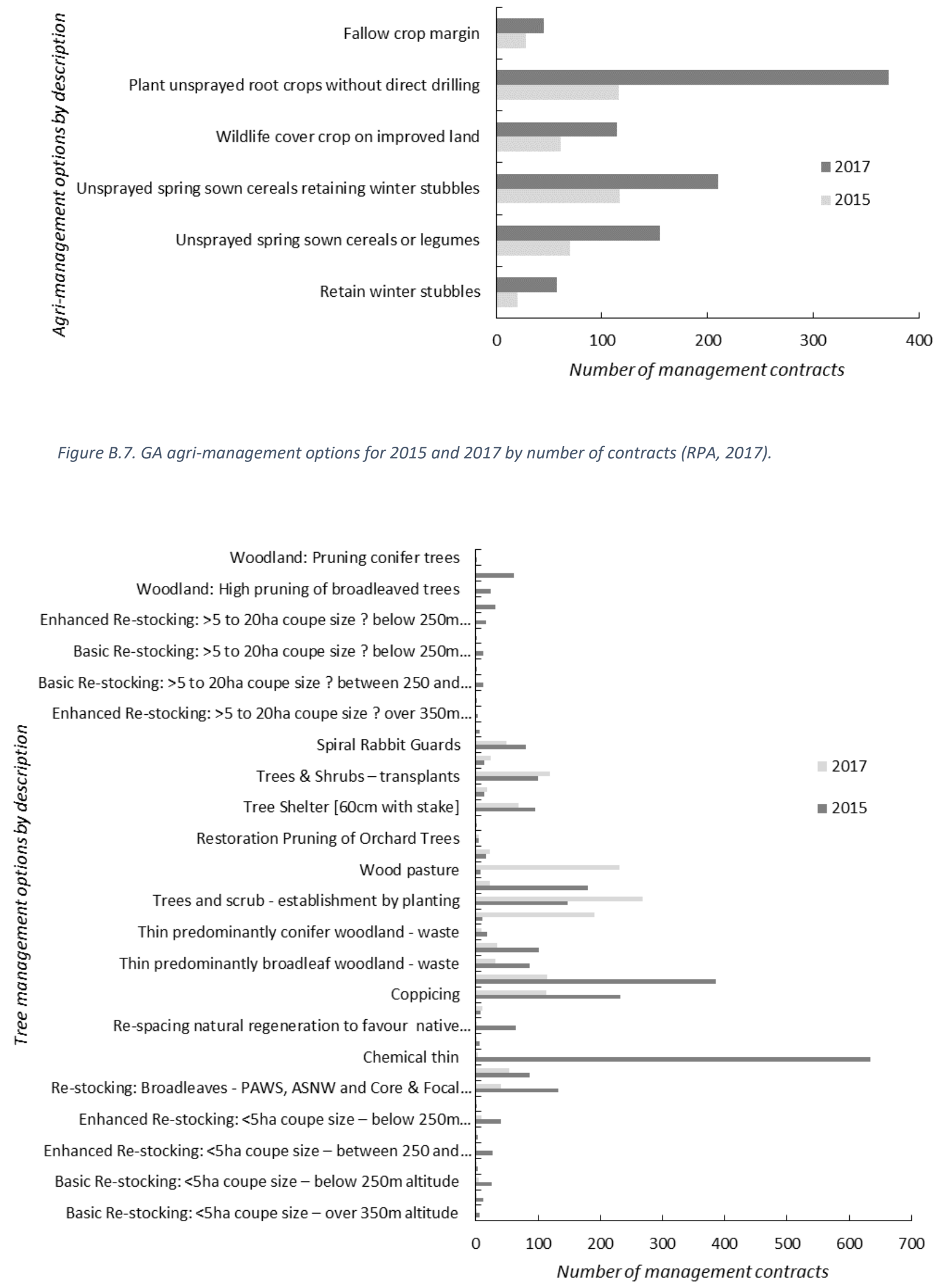

Figure B.8. GA tree management options for 2015 and 2017 by number of management contracts (RPA, 2017). 


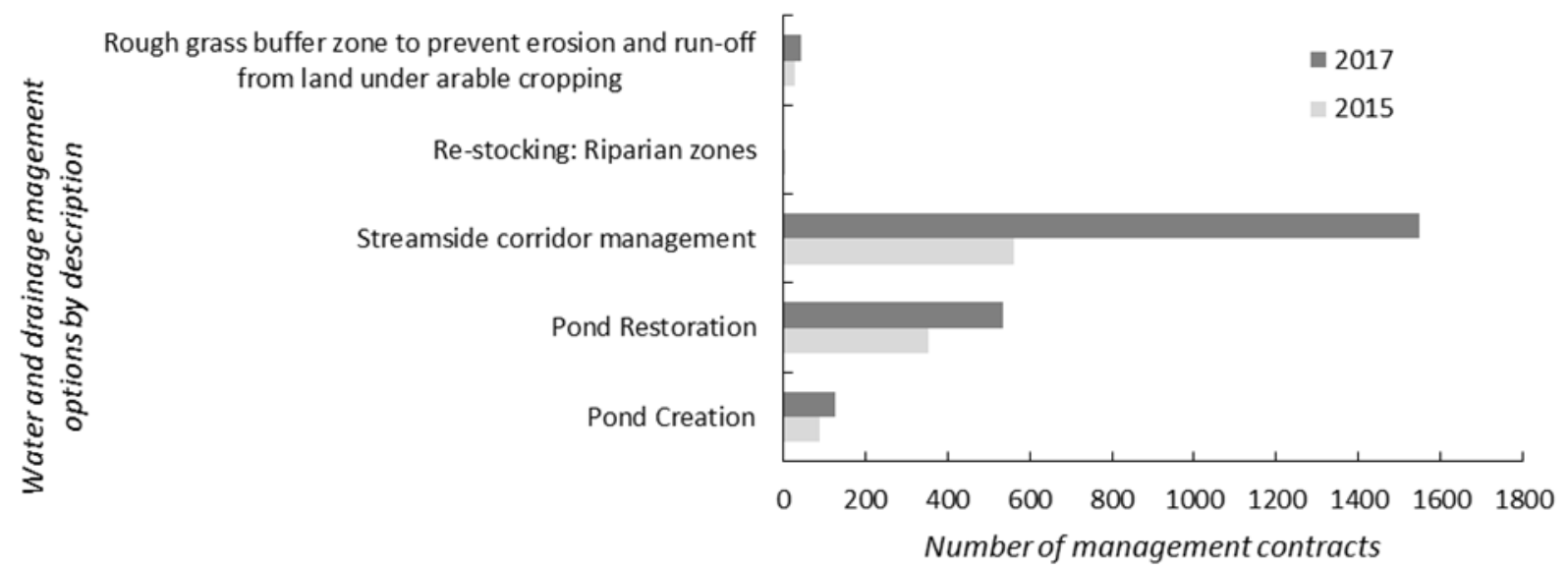

1171

Figure B.9. GA water and drainage management options for 2015 and 2017 by number of management contracts (RPA, 2017).

1174

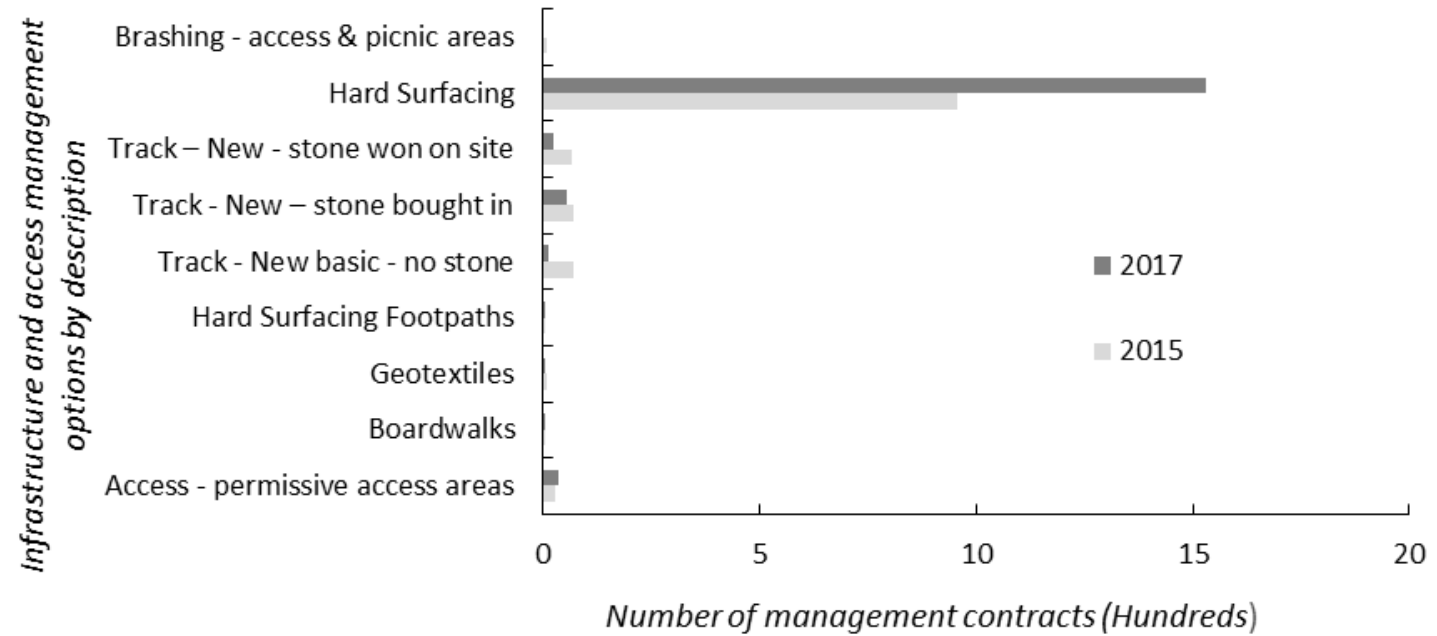
contracts (RPA, 2017).

1178

1179 Appendix C: Allocation of CAP spending 


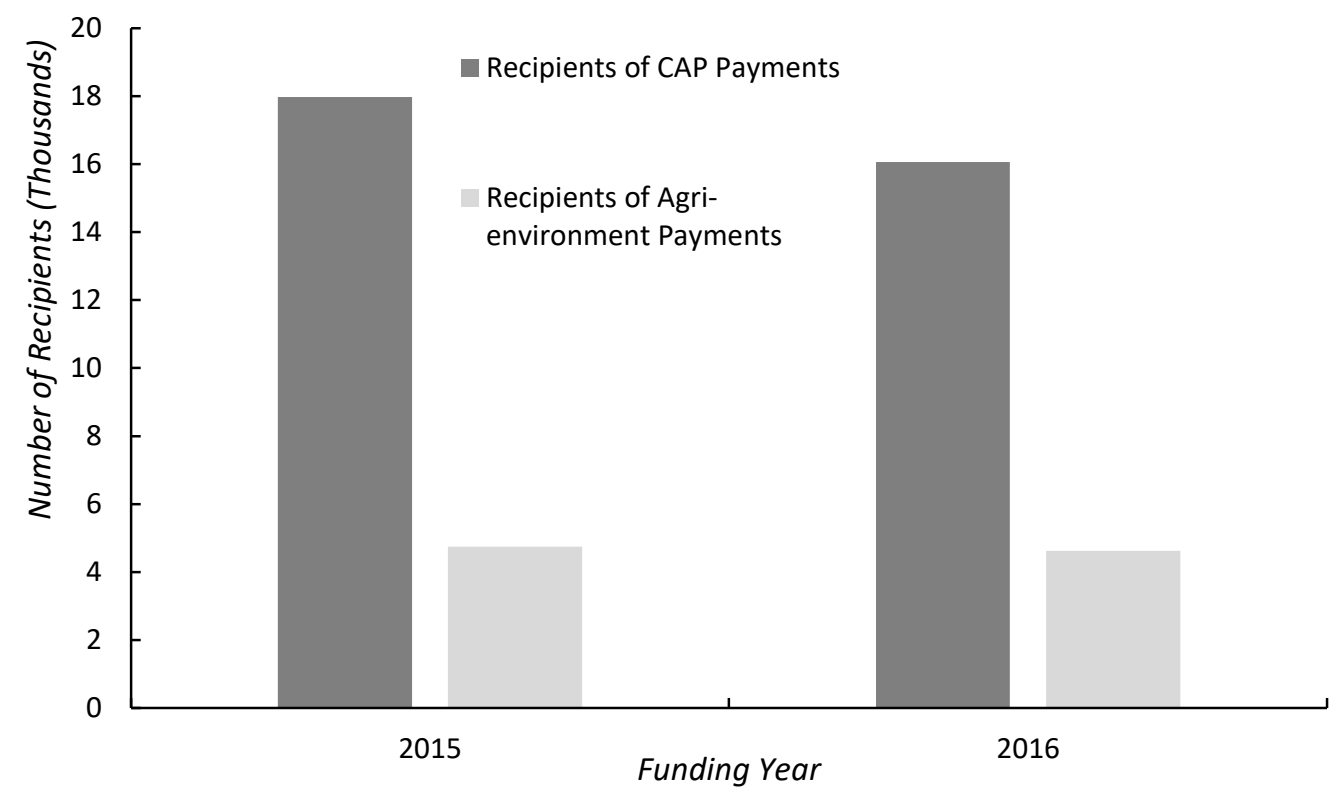

Figure C.11. Number of recipients of CAP payment (Pillar 1 and Pillar 2) and the number of recipients receiving AES payments for 2015 and 2016 (DEFRA, 2017)

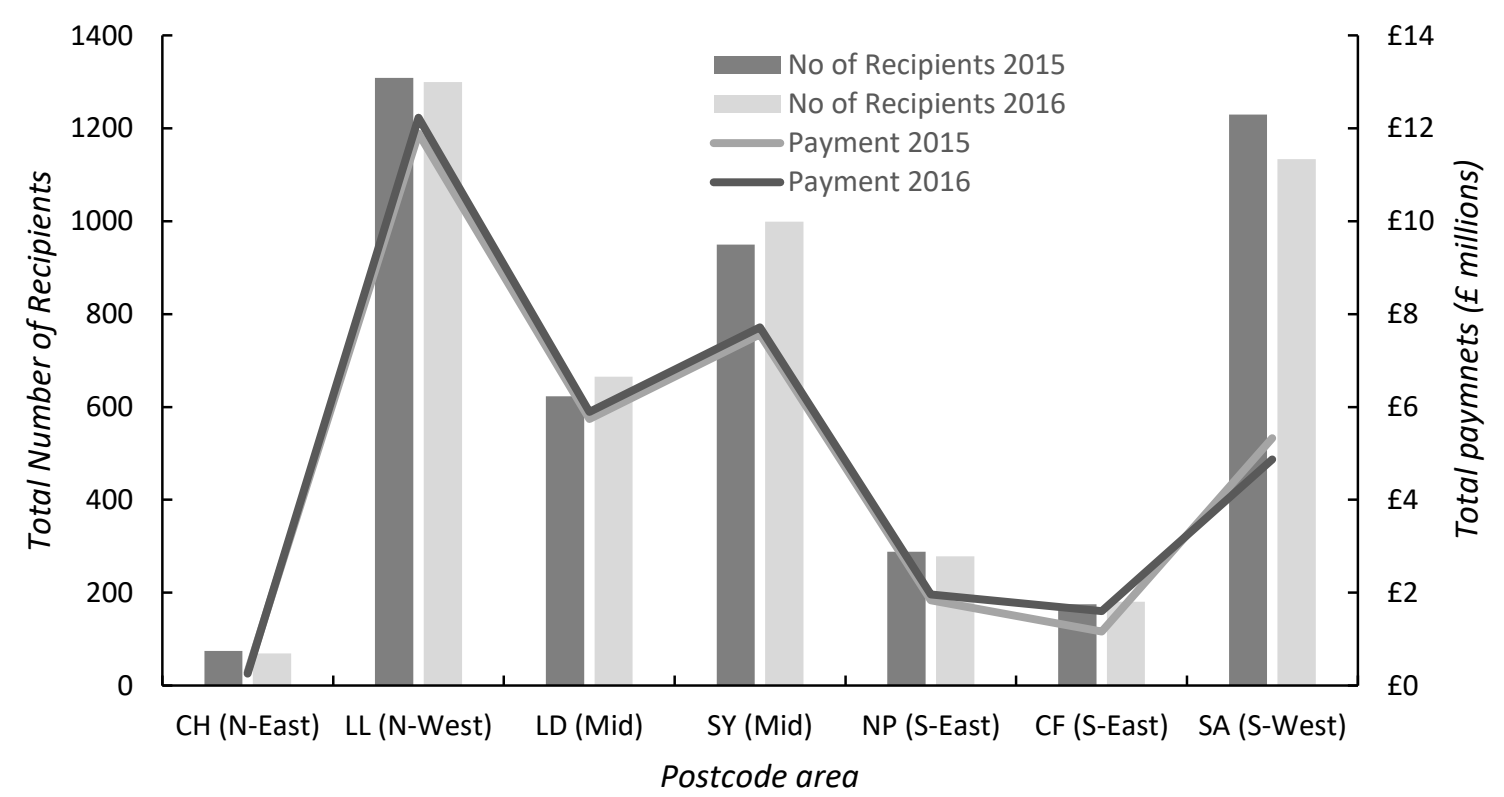

Figure C.2. Distribution of AES payments and recipients across the post code areas and regions of wales. Postcode areas identify the primary town or city in the region. 


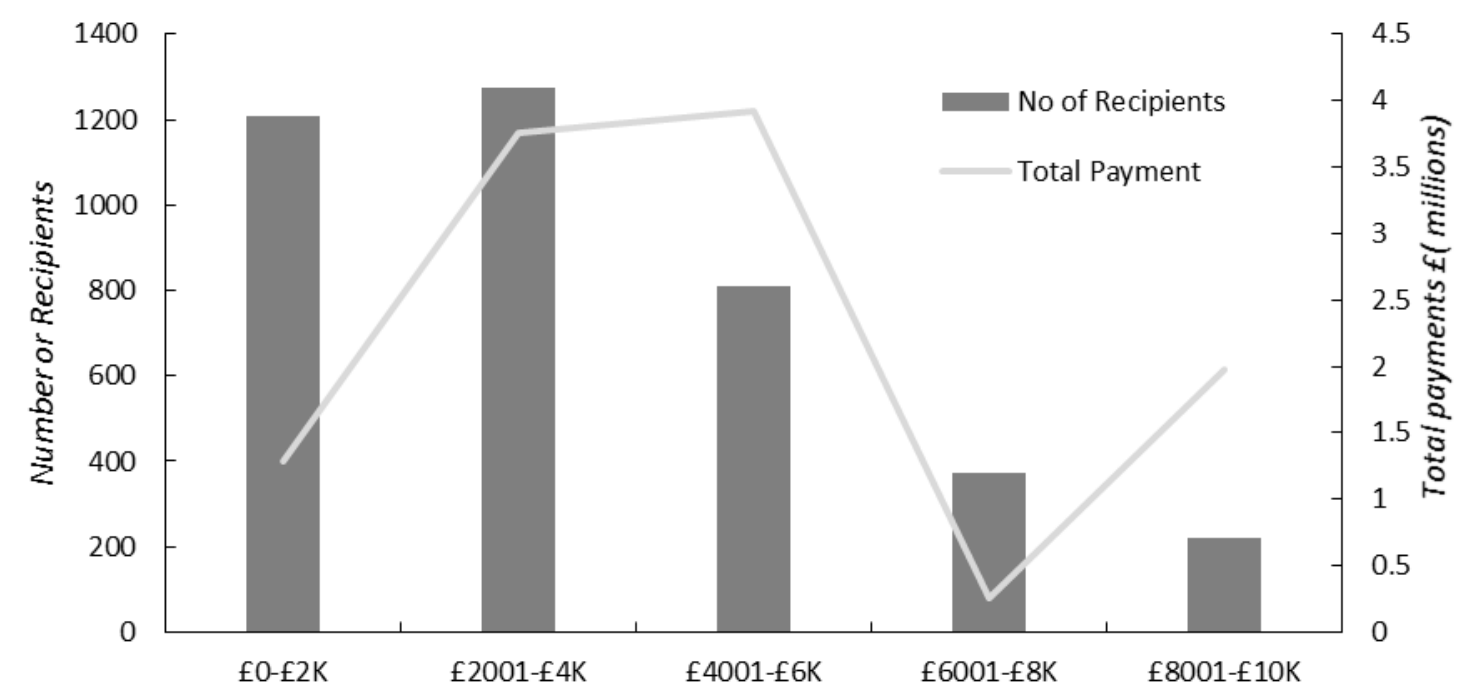

Figure C.3. Distribution of 2016 AES payments showing the total number of recipients and the total payments received across the $£ 0-10 K$ payment range. (DEFRA, 2017).

1190 Table C.3. GA management option descriptions. The table shows the option number and the total number of 1191 management contracts awarded by year (Option count) (RPA, 2017).

\begin{tabular}{|c|c|c|c|c|}
\hline Description & $\begin{array}{l}\text { Option } \\
\text { Number }\end{array}$ & $\begin{array}{l}\text { Option } \\
\text { count } \\
2017\end{array}$ & $\begin{array}{l}\text { Option } \\
\text { Number }\end{array}$ & $\begin{array}{l}\text { Option } \\
\text { count } \\
2015\end{array}$ \\
\hline Enhanced hedgerow management - both sides & 5 & 1095 & 5 & 287 \\
\hline grazed pasture - no inputs & 15 & 11391 & 15 & 4583 \\
\hline Management lowland marshy grassland & 19 & 2657 & 19 & 1133 \\
\hline Management lowland and coastal heath & 20 & 89 & 20 & 64 \\
\hline Management grazed saltmarsh & 21 & 66 & 21 & 21 \\
\hline Maintenance existing hay meadow & 22 & 1098 & 22 & 448 \\
\hline Management of sand dunes & 25 & 28 & 25 & 11 \\
\hline Fallow crop margin & 27 & 45 & 27 & 28 \\
\hline Retain winter stubbles & 28 & 57 & 28 & 20 \\
\hline Unsprayed spring sown cereals or legumes & 30 & 155 & 30 & 70 \\
\hline $\begin{array}{l}\text { Unsprayed spring sown cereals retaining winter } \\
\text { stubbles }\end{array}$ & 31 & 210 & 31 & 117 \\
\hline Wildlife cover crop on improved land & 33 & 114 & 33 & 61 \\
\hline Unharvested cereal headland & 34 & 3 & 34 & 3 \\
\hline Woodland - stock exclusion & 100 & 10438 & 100 & 5747 \\
\hline Trees and scrub - establishment by planting & 101 & 191 & 101 & 148 \\
\hline $\begin{array}{l}\text { Trees and scrub - establishment by natural } \\
\text { regeneration }\end{array}$ & 102 & 268 & 102 & 181 \\
\hline Scrub - stock exclusion & 103 & 437 & 103 & 214 \\
\hline Wood pasture & 104 & 23 & 104 & 8 \\
\hline Historic parks and gardens & 106 & 119 & 106 & 78 \\
\hline Calaminarian grassland & 109 & 1 & 109 & 1 \\
\hline Lowland dry heath with less than $50 \%$ western gorse & 115 & 87 & 115 & 44 \\
\hline $\begin{array}{l}\text { Lowland dry heath with more than } 50 \% \text { western } \\
\text { gorse }\end{array}$ & 116 & 60 & 116 & 24 \\
\hline
\end{tabular}




\begin{tabular}{|c|c|c|c|c|}
\hline $\begin{array}{l}\text { Lowland wet heath with less than } 60 \% \text { purple moor- } \\
\text { grass }\end{array}$ & 117 & 18 & 117 & 11 \\
\hline $\begin{array}{l}\text { Lowland wet heath with more than } 60 \% \text { purple } \\
\text { moor-grass }\end{array}$ & 118 & 19 & 118 & 11 \\
\hline $\begin{array}{l}\text { Lowland heath habitat expansion - establishment on } \\
\text { grassland }\end{array}$ & 119 & 56 & 119 & 39 \\
\hline Lowland unimproved acid grassland & 120 & 636 & 120 & 465 \\
\hline $\begin{array}{l}\text { Lowland unimproved acid grassland - reversion } \\
\text { (pasture) }\end{array}$ & 121 & 270 & 121 & 196 \\
\hline $\begin{array}{l}\text { Lowland unimproved acid grassland - reversion (hay } \\
\text { cutting) }\end{array}$ & 122 & 51 & 122 & 36 \\
\hline Lowland unimproved neutral grassland - pasture & 123 & 358 & 123 & 245 \\
\hline $\begin{array}{l}\text { Lowland unimproved neutral grassland - } \\
\text { haymeadow }\end{array}$ & 124 & 390 & 124 & 244 \\
\hline $\begin{array}{l}\text { Lowland unimproved neutral grassland - reversion } \\
\text { (pasture) }\end{array}$ & 125 & 345 & 125 & 251 \\
\hline $\begin{array}{l}\text { Lowland unimproved neutral grassland - reversion } \\
\text { (hay cutting) }\end{array}$ & 126 & 225 & 126 & 168 \\
\hline Lowland unimproved calcareous grassland & 128 & 50 & 128 & 20 \\
\hline $\begin{array}{l}\text { Lowland unimproved calcareous grassland - } \\
\text { reversion (pasture) }\end{array}$ & 129 & 9 & 129 & 4 \\
\hline $\begin{array}{l}\text { Lowland unimproved calcareous grassland - } \\
\text { reversion (hay cutting) }\end{array}$ & 130 & 11 & 130 & 7 \\
\hline Conversion from arable to grassland (no inputs) & 131 & 50 & 131 & 24 \\
\hline $\begin{array}{l}\text { Conversion from improved grassland to semi- } \\
\text { Improved grassland (hay cutting) }\end{array}$ & 132 & 129 & 132 & 88 \\
\hline Lowland marshy grassland & 133 & 2758 & 133 & 1705 \\
\hline Lowland marshy grassland - reversion (pasture) & 134 & 121 & 134 & 68 \\
\hline $\begin{array}{l}\text { Lowland bog and other acid mires with less than } \\
50 \% \text { purple moor-grass }\end{array}$ & 139 & 112 & 139 & 68 \\
\hline $\begin{array}{l}\text { Lowland bog and other acid mires with more than } \\
50 \% \text { purple moor-grass }\end{array}$ & 140 & 113 & 140 & 59 \\
\hline $\begin{array}{l}\text { Lowland bog and other acid mires - restoration (no } \\
\text { grazing) }\end{array}$ & 141 & 41 & 141 & 16 \\
\hline $\begin{array}{l}\text { Lowland bog and other acid mires - reversion } \\
\text { (pasture) }\end{array}$ & 142 & 23 & 142 & 17 \\
\hline Lowland fen & 143 & 102 & 143 & 45 \\
\hline Lowland fen - restoration (no grazing) & 144 & 6 & 144 & 4 \\
\hline Lowland fen - reversion (pasture) & 145 & 9 & 145 & 10 \\
\hline Reedbed - stock exclusion & 146 & 76 & 146 & 30 \\
\hline Reedbed - creation & 147 & 3 & 147 & 3 \\
\hline Coastal grassland (maritime cliff and slope) & 148 & 129 & 148 & 93 \\
\hline Saltmarsh - restoration (no grazing) & 149 & 45 & 149 & 22 \\
\hline Saltmarsh - creation & 150 & 4 & 150 & 1 \\
\hline Coastal vegetated shingle and sand dunes - creation & 151 & 1 & 151 & 1 \\
\hline Red clover ley & 153 & 64 & 153 & 33 \\
\hline $\begin{array}{l}\text { Buffer zones to prevent erosion and runoff from } \\
\text { grassland }\end{array}$ & 156 & 493 & 156 & 296 \\
\hline $\begin{array}{l}\text { Buffer zones to prevent erosion and runoff from } \\
\text { grassland - ditch landscapes }\end{array}$ & 157 & 56 & 157 & 46 \\
\hline
\end{tabular}




\begin{tabular}{|c|c|c|c|c|}
\hline $\begin{array}{l}\text { Buffer zones to prevent erosion or run-off from land } \\
\text { under arable cropping }\end{array}$ & 158 & 81 & 158 & 34 \\
\hline $\begin{array}{l}\text { Grassland managed with no inputs between } 15 \\
\text { October and } 31 \text { January }\end{array}$ & 159 & 631 & 159 & 239 \\
\hline $\begin{array}{l}\text { No lime on improved or semi-improved grassland } \\
\text { over peat soils }\end{array}$ & 160 & 31 & 160 & 14 \\
\hline Grassland management for chough (feeding) & 161 & 258 & 161 & 170 \\
\hline $\begin{array}{l}\text { Grassland management for curlew (nesting and } \\
\text { chick feeding) }\end{array}$ & 164 & 43 & 164 & 20 \\
\hline Grassland management for curlew (adult feeding) & 165 & 72 & 165 & 32 \\
\hline Haymeadow management for curlew (nesting) & 166 & 15 & 166 & 9 \\
\hline Grassland management for golden plover (feeding) & 167 & 2 & 167 & 1 \\
\hline $\begin{array}{l}\text { Grassland management for lapwing (nesting and } \\
\text { feeding) }\end{array}$ & 168 & 53 & 168 & 31 \\
\hline $\begin{array}{l}\text { Unsprayed spring sown cereals, oil seed rape, } \\
\text { linseed or mustard crop for lapwing (nesting) }\end{array}$ & 169 & 2 & 169 & 2 \\
\hline Uncropped fallow plot for lapwing (nesting) & 170 & 2 & 170 & 3 \\
\hline Grassland management for ring ouzel (feeding) & 171 & 12 & 171 & 8 \\
\hline Orchard management & 172 & 231 & 172 & 133 \\
\hline Streamside corridor management & 173 & 1549 & 173 & 560 \\
\hline $\begin{array}{l}\text { Rough grass buffer zone to prevent erosion and run- } \\
\text { off from land under arable cropping }\end{array}$ & 174 & 43 & 174 & 29 \\
\hline Management of rough grassland - enclosed land & 175 & 169 & 175 & 92 \\
\hline $\begin{array}{l}\text { Additional Management Payment - Stock } \\
\text { management }\end{array}$ & 400 & 290 & 400 & 110 \\
\hline Additional Management Payment - Mixed grazing & 401 & 504 & 401 & 355 \\
\hline $\begin{array}{l}\text { Additional Management Payment - Control burning } \\
\text { first } 0.00-3.00 \text { ha }\end{array}$ & 402 & 29 & 402 & 74 \\
\hline Additional Management Payment - Re-wetting & 403 & 82 & 403 & 33 \\
\hline $\begin{array}{l}\text { Additional Management Payment - Grazing } \\
\text { management for dung invertebrates }\end{array}$ & 405 & 31 & 405 & 17 \\
\hline Additional Management Payment - Reduce stocking & 411 & 2246 & 411 & 1034 \\
\hline Access - permissive access areas & 505 & 36 & 505 & 29 \\
\hline Boardwalks & 508 & 2 & 508 & 2 \\
\hline Geotextiles & 511 & 2 & 511 & 7 \\
\hline Hard Surfacing Footpaths & 512 & 1 & 512 & 1 \\
\hline Track - New basic - no stone & 526 & 11 & 526 & 70 \\
\hline Track - New - stone bought in & 527 & 53 & 527 & 69 \\
\hline Track - New - stone won on site & 528 & 24 & 528 & 65 \\
\hline $\begin{array}{l}\text { Squirrel hoppers - for control of grey squirrels } \\
\text { outside red squirrel areas }\end{array}$ & 550 & 1 & 550 & 16 \\
\hline Establish Red Clover Lay & 551 & 50 & 551 & 30 \\
\hline Hard Surfacing & 552 & 1531 & 552 & 955 \\
\hline Pond Creation & 564 & 128 & 564 & 87 \\
\hline Pond Restoration & 565 & 534 & 565 & 352 \\
\hline Establish Grass Lay & 581 & 41 & 581 & 27 \\
\hline Removal of Conifers & 605 & 23 & 605 & 17 \\
\hline Restoration Pruning of Orchard Trees & 606 & 5 & 606 & 5 \\
\hline
\end{tabular}




\begin{tabular}{|c|c|c|c|c|}
\hline Tree Pollarding & 607 & 2 & 607 & 2 \\
\hline Tree Shelter [60 cm with stake] & 608 & 69 & 608 & 95 \\
\hline Trees - Standards & 610 & 18 & 610 & 14 \\
\hline Trees and Shrubs - transplants & 611 & 120 & 611 & 100 \\
\hline Trees and Shrubs - Whips & 612 & 24 & 612 & 14 \\
\hline $\begin{array}{l}\text { Basic Re-stocking: <5ha coupe size - over } 350 \mathrm{~m} \\
\text { altitude }\end{array}$ & 613 & 2 & 613 & 6 \\
\hline $\begin{array}{l}\text { Basic Re-stocking: }<5 \text { ha coupe size - between } 250 \\
\text { and } 350 \mathrm{~m} \text { altitude }\end{array}$ & 616 & 2 & 616 & 12 \\
\hline $\begin{array}{l}\text { Basic Re-stocking: }<5 \text { ha coupe size - below } 250 \mathrm{~m} \\
\text { altitude }\end{array}$ & 619 & 5 & 619 & 25 \\
\hline $\begin{array}{l}\text { Enhanced Re-stocking: <5ha coupe size - over } 350 \mathrm{~m} \\
\text { altitude }\end{array}$ & 622 & 1 & 622 & 3 \\
\hline $\begin{array}{l}\text { Enhanced Re-stocking: }<5 \text { ha coupe size - between } \\
250 \text { and } 350 \mathrm{~m} \text { altitude }\end{array}$ & 625 & 2 & 625 & 27 \\
\hline $\begin{array}{l}\text { Enhanced Re-stocking: }>5 \text { to } 20 \text { ha coupe size }- \\
\text { between } 250 \text { and } 350 \mathrm{~m} \text { altitude }\end{array}$ & 626 & 2 & 626 & 4 \\
\hline $\begin{array}{l}\text { Enhanced Re-stocking: < } 5 \text { ha coupe size }- \text { below } \\
250 \mathrm{~m} \text { altitude }\end{array}$ & 628 & 9 & 628 & 41 \\
\hline $\begin{array}{l}\text { Enhanced Re-stocking: >20ha coupe size - below } \\
250 \mathrm{~m} \text { altitude }\end{array}$ & 630 & 1 & 630 & 1 \\
\hline $\begin{array}{l}\text { Re-stocking: Broadleaves - PAWS, ASNW and Core } \\
\text { and Focal networks }\end{array}$ & 631 & 40 & 631 & 132 \\
\hline Re-stocking: Broadleaves - All other sites & 632 & 54 & 632 & 87 \\
\hline Chemical thin & 634 & 3 & 634 & 5 \\
\hline Clear fell conifer and extract using skyline on PAWS & 635 & 2 & 635 & 6 \\
\hline $\begin{array}{l}\text { Re-spacing natural regeneration to favour native } \\
\text { broadleaved species or mixed woodland }\end{array}$ & 636 & 2 & 636 & 64 \\
\hline Coppicing & 644 & 113 & 644 & 236 \\
\hline Sabre Planting [no fence planting] & 646 & 10 & 646 & 8 \\
\hline Spiral Rabbit Guards & 647 & 49 & 647 & 81 \\
\hline Bracken Control - Aerial Spraying & 650 & 352 & 650 & 202 \\
\hline Bracken Control - Hand Knapsack Sprayer & 651 & 544 & 651 & 261 \\
\hline Bracken Control - Mechanical Two Cuts/Yr & 652 & 824 & 652 & 481 \\
\hline Bracken Control - Tractor Mounted Sprayer & 653 & 101 & 653 & 50 \\
\hline Bramble / Scrub Control - Hand Knapsack Spraying & 654 & 54 & 654 & 31 \\
\hline Heather management by burning & 656 & 26 & 656 & 57 \\
\hline Heather management by cutting & 657 & 141 & 657 & 125 \\
\hline Reed Cutting & 660 & 15 & 660 & 5 \\
\hline Reed Planting - Bought in seed & 661 & 4 & 661 & 5 \\
\hline Rhododendron Control - <1.5m & 663 & 108 & 663 & 85 \\
\hline Rush / Molinia Management - mechanical control & 664 & 330 & 664 & 233 \\
\hline Scrub Clearance - hand & 665 & 1028 & 665 & 693 \\
\hline Scrub Clearance - mechanical & 666 & 267 & 666 & 165 \\
\hline Sward Enhancement Using Native Seed & 667 & 16 & 667 & 6 \\
\hline Weed Wiping & 668 & 44 & 668 & 43 \\
\hline Invasive Plant Species control & 669 & 365 & 669 & 305 \\
\hline Rhododendron clearance - $>2.5 \mathrm{~m}$ & 670 & 56 & 670 & 93 \\
\hline
\end{tabular}




\begin{tabular}{|c|c|c|c|c|}
\hline Rhododendron Control -1.5 to $2.5 \mathrm{~m}$ & 671 & 78 & 671 & 90 \\
\hline $\begin{array}{l}\text { Ride and open ground mechanised mowing for } \\
\text { conservation reasons }\end{array}$ & 672 & 7 & 672 & 12 \\
\hline Geojute Matting & 681 & 7 & 681 & 0 \\
\hline Heather cutting and removal & 683 & 1 & 683 & 18 \\
\hline Thin predominantly broadleaf woodland - extract & 684 & 115 & 684 & 386 \\
\hline Thin predominantly broadleaf woodland - waste & 685 & 31 & 685 & 87 \\
\hline Thin predominantly conifer woodland - extract & 686 & 34 & 686 & 102 \\
\hline Thin predominantly conifer woodland - waste & 687 & 5 & 687 & 18 \\
\hline Ring Barking & 688 & 9 & 688 & 10 \\
\hline Grazed pasture - low inputs & $15 b$ & 2531 & $15 b$ & 1996 \\
\hline Grazed pasture - no inputs and mixed grazing & $15 c$ & 619 & $15 c$ & 227 \\
\hline Grazed pasture - low inputs and mixed grazing & $15 d$ & 410 & $15 d$ & 339 \\
\hline $\begin{array}{l}\text { Management lowland marshy grassland with mixed } \\
\text { grazing }\end{array}$ & $19 b$ & 144 & $19 \mathrm{~b}$ & 100 \\
\hline $\begin{array}{l}\text { Management lowland and coastal heath with mixed } \\
\text { grazing }\end{array}$ & $20 b$ & 2 & $20 \mathrm{~b}$ & 1 \\
\hline Management grazed saltmarsh with mixed grazing & $21 b$ & 24 & $21 b$ & 15 \\
\hline Management of sand dunes with mixed grazing & $25 b$ & 10 & $25 b$ & 5 \\
\hline Plant unsprayed root crops without direct drilling & $32 b$ & 371 & $32 b$ & 116 \\
\hline Unfertilised and unsprayed cereal headland & $34 b$ & 11 & $34 b$ & 8 \\
\hline Grazing management of open country & $41 a$ & 1671 & $41 a$ & 591 \\
\hline $\begin{array}{l}\text { Grazing management of open country with mixed } \\
\text { grazing }\end{array}$ & $41 b$ & 140 & $41 \mathrm{~b}$ & 66 \\
\hline Brashing: access and picnic areas & & & 520 & 7 \\
\hline $\begin{array}{l}\text { Basic Re-stocking: >20ha coupe size: over 350m } \\
\text { altitude }\end{array}$ & & & 615 & 7 \\
\hline $\begin{array}{l}\text { Basic Re-stocking: }>5 \text { to } 20 \text { ha coupe size between } \\
250 \text { and } 350 \mathrm{~m} \text { altitude }\end{array}$ & & & 617 & 12 \\
\hline $\begin{array}{l}\text { Basic Re-stocking: >20ha coupe size: between } 250 \\
\text { and } 350 \mathrm{~m} \text { altitude }\end{array}$ & & & 618 & 2 \\
\hline $\begin{array}{l}\text { Basic Re-stocking: }>5 \text { to } 20 \text { ha coupe size: below } \\
250 \mathrm{~m} \text { altitude }\end{array}$ & & & 620 & 12 \\
\hline $\begin{array}{l}\text { Enhanced Re-stocking: }>5 \text { to } 20 \text { ha coupe size: over } \\
350 \mathrm{~m} \text { altitude }\end{array}$ & & & 623 & 3 \\
\hline $\begin{array}{l}\text { Enhanced Re-stocking: }>20 \text { ha coupe size: over } 350 \mathrm{~m} \\
\text { altitude }\end{array}$ & & & 624 & 2 \\
\hline $\begin{array}{l}\text { Enhanced Re-stocking: >20ha coupe size: between } \\
250 \text { and } 350 \mathrm{~m} \text { altitude }\end{array}$ & & & 627 & 1 \\
\hline $\begin{array}{l}\text { Enhanced Re-stocking: }>5 \text { to } 20 \text { ha coupe size: below } \\
250 \mathrm{~m} \text { altitude }\end{array}$ & & & 629 & 17 \\
\hline Re-stocking: Riparian zones & & & 633 & 4 \\
\hline Heather restoration by seed and mulch & & & 658 & 7 \\
\hline Woodland: Formative pruning of broadleaved trees & & & 694 & 31 \\
\hline Woodland: High pruning of broadleaved trees & & & 695 & 24 \\
\hline Woodland - light grazing & & & 176 & 62 \\
\hline Woodland: Pruning conifer trees & & & 696 & 1 \\
\hline Total number of individual option contracts & \multicolumn{2}{|l|}{55248} & & 30531 \\
\hline
\end{tabular}


management contracts awarded by year (Option count) (RPA, 2017).

\begin{tabular}{|c|c|c|}
\hline Description & $\begin{array}{l}\text { Option } \\
\text { Number }\end{array}$ & $\begin{array}{l}\text { Option } \\
\text { Count } \\
2017\end{array}$ \\
\hline $3 \mathrm{~m}$ wildlife corridor - include trees and shrubs & 1 & 169 \\
\hline $3 \mathrm{~m}$ wildlife corridor include earth bank and tree/shrub planting & 2 & 114 \\
\hline Wildlife corridor - wooded strip & 3 & 104 \\
\hline Hedgerow management - both sides & 4 & 3253 \\
\hline Enhanced hedgerow management - both sides & 5 & 2180 \\
\hline Double fence gappy hedges $3 \mathrm{~m}$ width & 6 & 571 \\
\hline Continued management of existing streamside corridor & 8 & 2886 \\
\hline Restore traditional orchard & 11 & 114 \\
\hline Create new orchard & 12 & 192 \\
\hline Plant individual trees & 13 & 403 \\
\hline Grazed pasture - no inputs & 15 & 10759 \\
\hline Upland Heath & 16 & 25 \\
\hline Blanket Bog & 17 & 9 \\
\hline Upland Grassland & 18 & 125 \\
\hline Management lowland marshy grassland & 19 & 5306 \\
\hline Management lowland and coastal heath & 20 & 82 \\
\hline Management grazed saltmarsh & 21 & 82 \\
\hline Maintenance existing hay meadow & 22 & 1634 \\
\hline Small areas in corners of field revert to rough grassland/scrub & 23 & 272 \\
\hline Woodland edge to develop out to adjoining (improved) fields & 24 & 16 \\
\hline Management of sand dunes & 25 & 17 \\
\hline Fixed rough grass margins on arable land & 26 & 214 \\
\hline Fallow crop margin & 27 & 39 \\
\hline Retain winter stubbles & 28 & 154 \\
\hline Undersown spring cereals next to watercourses & 29 & 17 \\
\hline Unsprayed spring sown cereals or legumes & 30 & 510 \\
\hline Unsprayed spring sown cereals retaining winter stubbles & 31 & 146 \\
\hline Unsprayed root crops on improved land & 32 & 676 \\
\hline Wildlife cover crop on improved land & 33 & 218 \\
\hline Unharvested cereal headland & 34 & 4 \\
\hline Create wildlife pond - enclosed improved land & 35 & 36 \\
\hline Buffering existing unfenced in-field ponds & 36 & 55 \\
\hline Management of scrub etc from historic features & 39 & 26 \\
\hline Fence around stock excluded woodland & 40 & 806 \\
\hline Mechanical bracken control & 44 & 343 \\
\hline Maintenance of traditional weatherproof buildings & 45 & 251 \\
\hline Grazed pasture - low inputs & $15 b$ & 10547 \\
\hline Grazed pasture - no inputs and mixed grazing & $15 c$ & 1201 \\
\hline Grazed pasture - low inputs and mixed grazing & $15 d$ & 2105 \\
\hline Management lowland marshy grassland with mixed grazing & $19 b$ & 412 \\
\hline $2 \mathrm{~m}$ wildlife corridor- tree and shrub planting & $1 b$ & 298 \\
\hline
\end{tabular}


Management lowland and coastal heath with mixed grazing

Management grazed saltmarsh with mixed grazing

$2 \mathrm{~m}$ wildlife corridor include earth bank and tree/shrub planting

Plant unsprayed root crops without direct drilling

Unfertilised and unsprayed cereal headland

Wildlife pond on enclosed land - variable size

Grazing management of open country

Grazing management of open country with mixed grazing

Hedgerow restoration with fencing

Hedgerow restoration without fencing

Double fence and restore hedge banks with planting

Double fence and restore hedge banks without planting

Maintenance linear permissive access - Tir Gofal bridleway

Maintenance linear permissive access - Tir Gofal footpath

Create a streamside corridor on improved land on one side of a watercourse

Create a streamside corridor on improved land on one side of a watercourse with 